\title{
Pollution and respiratory disease: can diet or supplements help? A review
}

\author{
T. Whyand ${ }^{1}$, J. R. Hurst ${ }^{2}$, M. Beckles ${ }^{3}$ and M. E. Caplin ${ }^{1 *}$
}

\begin{abstract}
Pollution is known to cause and exacerbate a number of chronic respiratory diseases. The World Health Organisation has placed air pollution as the world's largest environmental health risk factor. There has been recent publicity about the role for diet and anti-oxidants in mitigating the effects of pollution, and this review assesses the evidence for alterations in diet, including vitamin supplementation in abrogating the effects of pollution on asthma and other chronic respiratory diseases. We found evidence to suggest that carotenoids, vitamin $\mathrm{D}$ and vitamin $\mathrm{E}$ help protect against pollution damage which can trigger asthma, COPD and lung cancer initiation. Vitamin C, curcumin, choline and omega-3 fatty acids may also play a role. The Mediterranean diet appears to be of benefit in patients with airways disease and there appears to be a beneficial effect in smokers however there is no direct evidence regarding protecting against air pollution. More studies investigating the effects of nutrition on rapidly rising air pollution are urgently required. However it is very difficult to design such studies due to the confounding factors of diet, obesity, co-morbid illness, medication and environmental exposure.
\end{abstract}

Keywords: Pollution, Diet, Lungs, Supplements, Asthma, COPD, Smoke, Particulates, Vitamins, Omega-3, Curcumin

\section{Background}

The World Health Organisation (WHO) released a report in 2014 indicating that 3.7 million premature deaths globally were attributable to ambient air pollution [1]. Their data more than doubled previous estimates and placed air pollution as the world's largest environmental health risk factor [1]. The majority of outdoor pollutants come from anthropogenic sources such as vehicle emissions, fossil fuel combustion, forest fires and industrial processes including factory outputs [2]. The WHO showed that in urban areas which monitor air pollution levels, greater than $80 \%$ of people are exposed to levels of pollution which exceed WHO limits [1]. Primary pollutants can be divided into two groups: particulate matter (PM) and gases (CO2, CO, NO2, NO, NOx, SO2) [2]. Secondary pollutants such as ozone are formed from photochemical reactions between the primary pollutants, heat and UV radiation. Other environmental air pollutants of major public concern include polycyclic aromatic hydrocarbons (PAHs) and aryl hydrocarbon receptors (AhR).

\footnotetext{
* Correspondence: m.caplin@ucl.ac.uk

${ }^{1}$ Centre for Gastroenterology, Royal Free Hospital, London NW3 2QG, UK Full list of author information is available at the end of the article
}

There has been increasing research on the effects of ambient pollution on health. Pollution causes damage when it is in contact with the airways and skin. For example, some pollutants can accumulate in the blood and be distributed in digestive organs, purely through inhalation [3]. Pollutants also act on the exterior of the body and have been linked to the progression of inflammatory skin diseases [2, 4-9]. Many studies have demonstrated the effects of exposure to environmental pollutants via skin, inhalation or ingestion on morbidity and mortality $[9,10]$.

The lungs rely on filtered air through the nose (with cilia and mucus attempting to filter/trap unwanted particles) or unfiltered air via the mouth. Polluted air contributes to chronic obstructive pulmonary disease (COPD) prevalence and symptom onset [11]. The idea that air pollution can cause exacerbations of pre-existing asthma is supported by an evidence base that has been accumulating for several decades [12-15], however it has more recently been suggested that air pollution might cause new-onset asthma as well [16-26].

In October 2013, a Working Group of invited experts from 11 countries met at the International Agency for Research on Cancer (IARC) in Lyon, France, to evaluate 
the carcinogenicity of outdoor air pollution. The Group unanimously classified outdoor air pollution and PM from outdoor air pollution as carcinogenic to humans (IARC Group 1) based on sufficient evidence of carcinogenicity in humans and experimental animals and strong mechanistic evidence [27].

In addition to outdoor air pollution, indoor smoke is a serious health risk for some 3 billion people who cook and heat their homes with biomass fuels and coal. Some 4.3 million premature deaths were attributable to household air pollution in 2012. Almost all of this burden is in low-middle-income countries [28]. When indoor and ambient air pollution are combined, WHO estimates that in 2012, some $14 \%$ of deaths were due to COPD or acute lower respiratory infections, and $14 \%$ of deaths were due to lung cancer [29].

There has been recent publicity on the role of diet helping to combat the effects of pollution and in this review we assess the role for diet in preventing the effects of pollution on asthma and other respiratory diseases.

\section{Method}

In 2017 to March 2018, a search of 'air pollution and diet,' 'pollution and diet,' 'pollution and antioxidants', 'pollution and fats' 'pollution diet and lung disease' 'pollution and respiratory disease, 'pollution and lung cancer', 'metabolism and air pollution', 'obesity and air pollution', 'Mediterranean diet and air pollution,' 'Western diet and air pollution' was conducted using PubMed. A search of original research and review papers from the past twenty years, dating back to 1997 resulted in 109 relevant papers of mainly original research being reviewed.

\section{Overview of pollutants Phthalates}

It is known that phthalates are widespread contaminants in both indoor and outdoor environments with the plastic industry being a major contributor. They are mainly added to plastics to increase their flexibility, transparency, durability, and longevity. They are used primarily to soften polyvinyl chloride (PVC). Studies suggest that diethylhexyl phthalate (DEHP), a high molecular species used in plastic wrapping of foods, is a major source of exposure for humans as a result of contamination from the packaging, an effect made greater with microwave heating. The toxicants can be delivered into the body via inhalation, dietary intake, and skin absorption inducing an inflammatory response [29]. Most experimental studies address the adjuvant effects of phthalates in immune responses [30] and they may contribute to airway remodelling [31] and affect respiratory health [32-36].

\section{Particulate matter}

PM is a complex mixture of particles found in the air, including dust, dirt, soot, smoke, and liquid droplets particles suspended in air and are produced by a variety of natural and anthropogenic activities [10]. Major sources of PM include open fires, industrial facilities, power plants and vehicle exhausts [10]. PM can be divided into three types depending on size; ultrafine particles (UFP), fine particles (PM2.5) and coarse particles (PM10). Due to the increase in urbanisation and industrial processes PM are widely implicated in contributing to ambient pollution worldwide and are associated with increased morbidity and mortality [10]. PM can penetrate the alveolar regions of the lung, pass through the cell membrane, reach the blood and can accumulate in other human organs [3]. Additionally, epidemiological investigations into contamination, especially ambient air pollution, indicated that the PM is not only correlative with the exacerbation of cardiovascular diseases and respiratory systemic inflammation, but also the progression of inflammatory skin diseases [2] such as atopic dermatitis (AD) [4-6], acne, psoriasis, and allergic reactions [7-9]. The metabolic effects of $\mathrm{PM}_{2.5}$ are also evident with significant increases in carcinoembryonic antigen and fasting blood glucose, and significant decreases in HDL cholesterol in Chinese policemen who work at least 1 hour a day outside for 1 year [37]. Additionally, $\mathrm{PM}_{2.5}$ inhalation reduces ATP production by disrupting the aerobic tricarboxylic acid cycle and oxidative phosphorylation, thereby causing the hypophosphorylation of tau in the cortices of middle-aged mice. Excessive reactive oxygen species generation was involved in the impairment, but interestingly, these alterations were partially reversed after exposure to $\mathrm{PM}_{2.5}$ had ended [38].

PM can induce oxidative stress and inflammation on respiratory organ tissue [39-42] exacerbating asthma [43, 44] and COPD [45-47]. Dust particles alone may mediate airway inflammation, the progression of asthmatic diseases [48] and pneumonia $[49,50]$. PM from different fuels and combustion phases have appreciable differences in lung toxic and mutagenic potency, and on a mass basis, flaming samples are more active, whereas smouldering samples have greater effect when emission factors are taken into account [51]. In another study, coarse PM from roadside air elicited a genotoxic response in the normal alveolar cell lines [52]. There are various population studies, and many from China, for example; an average of $23.1 \%$ lung cancer burden was attributable to PM2.5 pollution in Guangzhou during 2013 [53]. In the US Adventist Health and Smog Study-2 (AHSMOG-2) study increased risk estimates of lung cancer were observed for each $10-\mu \mathrm{g} / \mathrm{m}^{3}$ increment in ambient $\mathrm{PM}_{2.5}$ concentration. The estimate was higher among those with longer residence at enrolment address and those who spent $>1 \mathrm{hr} /$ day outdoors [54]. 


\section{Polycyclic aromatic hydrocarbons}

PAHs are generated during the incomplete combustion of organic matter and can form complex mixtures with airborne particulate matter or gases. The majority of outdoor PAHs are derived from coal tar, diesel exhausts and cigarette smoke. PAHs may be metabolically activated to generate reactive oxygen species (ROS) that can react to form bulky DNA adducts or strand breaks on cellular DNA [55]. PAH exposure has been linked to adverse respiratory health outcomes in children, including bronchitis [56, 57] and reductions in the forced expiratory volume, $\left(\mathrm{FEV}_{1}\right)$ [58-62]. Among adults in occupational settings, elevated PAH exposures have been found to be associated with declines in $\mathrm{FEV}_{1}$ /forced vital capacity (FVC) [63]. In an in vitro animal cell model, low molecular weight PAHs and benzo[a]pyrene (which are found together in cigarette smoke) elicited increased carcinogenic potential [64].

\section{Ozone}

Ground level ozone (O3) generation is a major component of smog and is formed as a result of a photochemical reaction between $\mathrm{O} 2$ and pollutants such as hydrocarbons and nitrous oxides, which is facilitated by sunlight. Excessive ozone in the air can have a marked effect on human health. It can cause breathing problems, trigger asthma, reduce lung function and cause lung diseases such as COPD [28]. Short-term exposure to ozone is associated with respiratory morbidity and mortality [65-68]. Long-term exposure has been linked to premature respiratory mortality in adults [69] and to increased risk of death in susceptible populations with chronic cardiopulmonary diseases and diabetes [70]. Less evidence is available for an association between ozone and lung cancer, with one Canadian study finding an odds ratio for lung cancer incidence of $1.09(0.85-1.39)$ with a 10 $\mathrm{U}$ increase in ozone [71] and another Canadian study found ozone was a non-significant contributor to lung cancer mortality [72].

\section{Nitrogen dioxide}

Ambient pollution is also characterised by increased levels of nitrogen dioxide $\left(\mathrm{NO}_{2}\right)$ and it is regarded as a strong marker for air pollution primarily generated from combustion including motor vehicles, biomass burning, airports and industry [73, 74]. A recent meta-analysis of 13 studies from across North America, Europe and Asia has shown a modest increase in the risk of respiratory mortality with increasing chronic exposure to $\mathrm{NO}_{2}[74,75]$. Exposure to ambient $\mathrm{NO}_{2}$ increases systemic inflammation in COPD patients, especially in former smokers [76]. Each 10 $\mu \mathrm{g} / \mathrm{m}^{3}$ increase in nitrogen dioxide corresponded to an increased risk for diagnosed asthma in 6-13-yearold Chinese children [77].

\section{Persistent organic pollutants}

Persistent organic pollutants (POPs) comprise a large variety of substances such as Polychlorinated biphenyls (PCBs) and Polybrominateddiphenyl ethers (PBDEs). PCBs are a persistent public health threat in indoor environments, because they were purposefully added to household sealants, paint plasticizers, wood finishes, flame retardants, light ballasts, and electrical capacitors in appliances $[78,79]$. Inadvertent production of PCBs is an additional, emerging concern. PCBs are present in modern pigments used in household paint and many consumer products $[80,81]$. PCBs are also present in outdoor environments due to contributions from contemporary urban sources, $[82,83]$ and, to a lesser amount, volatilisation from soil and water bodies [84-86].

PCBs are highly lipophilic; bioaccumulate in fats, lipids, and waxes; bioconcentrate in food chains; and are semi-volatile. In view of high $\mathrm{PCB}$ concentrations in some animals, studies of dietary PCB exposure have historically taken precedence over dermal and inhalation exposure. However, airborne emissions from newly produced PCBs may lead to inhalation exposure at levels comparable to, and sometimes higher than, dietary exposure [87-89]. There is also rising evidence that some PCBs are mutagenic and tumour promoting [90]. For example 2 cohorts of highly exposed populations in Asia developed high rates all cancers, lung cancer and liver disease (men) and liver cancer (women) [91]. This may be because PCBs appear to contribute to oxidative damage in the body [92-97].

\section{Mixed pollutants}

Air often contains a mixture of pollutants. In Chinese children, mixed pollutants (PM10, sulphur dioxide, nitrogen dioxides, and O3) have been linked to increased blood pressure, and obesity seemed to amplify these changes [98]. Another team however feel that the inhalation of traffic related air pollution causes obesity, by reducing children's physical activity and through inflammatory pathways [99]. There is also a relationship to inflammation initiating metabolic processes involved in diabetes development $[100,101]$.

Environmental tobacco smoke and chemical emissions from new furniture are risk factors for asthma [102] and for wheeze and daytime breathlessness [103]. Males without allergic predisposition and females with allergic predisposition had increased susceptibility to the adverse impact of air pollution on asthma [16]. Several other studies have also indicated that the airways of males and females respond differently to exposure to air pollutants 
[104-107]. This is plausible as there are differences between male and female airways from early in foetal lung development and throughout life [108, 109], for example female lungs mature earlier with regard to surfactant production. Throughout life, women have smaller lungs than men, but their lung architecture is more advantageous with a greater airway diameter in relation to the volume of the lung parenchyma. Thus, in childhood, airway hyper-responsiveness and asthma is more common among boys than girls. Among the children without an allergic predisposition, the stronger association between ambient air pollutants exposure and respiratory symptoms and diseases in males, could be related to males having less mature lungs and relatively narrower airways during childhood. These factors are believed to contribute to the generally higher rates of pulmonary morbidity in boys than in girls, and could possibly also explain a higher susceptibility for damage by exposure to air pollutants during this age window. Increased ambient ozone, $\mathrm{NO}_{2}, \mathrm{PM} 2 \cdot 5$, and sulphur dioxide $\left(\mathrm{SO}_{2}\right)$ levels were associated with increased hospital admission for asthma [110-114].

Many developing countries or regions (eg, rural China, India, South America and Sub-Saharan Africa) still use open fires for cooking or heating and despite mixed findings for biomass smoke exposure and asthma risk, coal combustion for heating and cooking conferred higher risks of childhood asthma in China [115]. In multi-pollutant models, black carbon conferred greater asthma admission risks for children, [116]. Moreover, the adverse effects and resulting diseases such as COPD from smoke pollution could be long lasting as the lungs are still developing into a person's early twenties. Another study demonstrated that each $15 \mu \mathrm{g} / \mathrm{m}^{3}$ and $50 \mu \mathrm{g} /$ $\mathrm{m}^{3}$ increase in $\mathrm{NO}_{2}$ and $\mathrm{SO}_{2}$ levels respectively was associated with an increased risk of asthma, whereas combined exposure to high levels of $\mathrm{NO}_{2}$ and $\mathrm{SO}_{2}$ further increased asthma risk in the first year of life [117]. A report in the USA has shown that early-life exposure to traffic-related air pollution correlated with $\mathrm{FEV}_{1} / \mathrm{FVC}$ [118]. Groups of pollutants have already been discussed in terms of their carcinogenic abilities, and it is clear that causes of lung cancer are changing. A study of 495 lung cancer patients in the Indian sub-continent found that incidence was higher among non-smokers [119]. This shows that the focus within lung cancer prevention needs to move from anti-tobacco public health messaging, to wider national and international policies to clean up air we are forced to breath.

\section{Nutrient protection}

Oxidative stress plays an important role in the development of age-related diseases [120].Evidence increasingly suggests that poor diet, including clinical malnutrition may increase the risk for oxidative stress and chronic diseases $[92-97,120]$. Nutrition is known to play a significant role in the prevention and management of these same chronic diseases and has been shown to modulate the toxicity of PCBs [93-97]. One study has suggested that there may be increased susceptibility to $\mathrm{NO}_{2}$ when someone is in a fasting state [121] but it is not known if it is the same for other pollutants.

Oxidative stress, resulting from an imbalance between reactive oxidant species and antioxidants, can lead to tissue damage, airway inflammation with increased asthma severity and abnormal immune responses [122-124]. Serum concentrations of antioxidants have been positively associated with $\mathrm{FEV}_{1}$ in people with and without asthma $[125,126]$. Vitamin, mineral and botanical compounds, with and without antioxidant properties will be discussed.

\section{Vitamin A and carotenoids}

Vitamin A contributes to key biological processes including growth, vision, epithelial differentiation, reproduction, and immune responses [127]. The two dietary sources of this vitamin are pre-formed vitamin A (retinol) and provitamin A (carotenoids) [128]. Dietary intake of retinol comes from animal sources (eg, whole milk, liver, and eggs) and fortified foods. Orange and yellow fruits and vegetables (eg, carrots) are the main dietary sources of carotenoids, including $\alpha$-carotene, $\beta$-carotene, lycopene and $\beta$-cryptoxanthins and they are known antioxidants [129]. Oxidative stress might exacerbate asthma by increasing the release of pro-inflammatory cytokines, which may lead to increased airway inflammation, and airway responsiveness $[122,123,130]$. Vitamin A might improve prevention or treatment of asthma by downregulation of oxidative stress [131], or via direct effects on the immune system [132] for example downregulation of T-helper (Th)2 (proallergic) immune responses [133, 134]. However, vitamin A also enhances protective Th2 immune responses (eg, interleukin (IL) 4 expression) [135]. Lycopene, (a carotenoid) supplementation was shown to reduce allergic airway inflammation, [136]. Self-reported dietary intake of vitamin A or its components (retinol and carotenoids) was inversely associated with asthma and asthma severity. However, dietary intake of vitamin A was not significantly associated with wheeze or airway responsiveness [137].

No primary randomised controlled trial (RCT) of vitamin A for the prevention or treatment of asthma has yet been performed. There are a number of studies of vitamin A supplementation, but such studies were difficult to control for dietary intake, and gave variable results [138-140]. However, higher intake of tomatoes, carrots, and leafy vegetables (which are rich in carotenoids such as $\alpha$-carotene, $\beta$-carotene, lutein, and zeaxanthin) has been associated with lower prevalence of asthma in 
women [141]. Of the pro-vitamin A carotenoids, $\beta$ carotene has been most intensely studied because of its protective properties against the effects of free radicals and oxidative damage. A meta-analysis of five observational studies showed that high dietary intake of $\beta$ carotene was not significantly associated with asthma or $\mathrm{FEV}_{1}$ [142]. However, this meta-analysis was limited by sample size and residual confounding. Results of two RCTs showed that modification of dietary intake of carotenoids through a diet rich in fruits and vegetables [143] or lycopene-rich tomato extract and tomato juice [144] improved indicators of asthma control, including lung function measures and time to disease exacerbations, in adults with asthma. Larger RCTs (including both children and adults) with longer follow-up are needed to further validate these findings.

According to World Cancer Research Fund/American Institute for Cancer Research (WCRF/AICR) Second Expert Report from 2007, foods rich in carotenoids may protect against lung cancer (strength graded as 'probable') [145]. However, in contrast, two large randomized double-blind placebo-controlled trials, the alphatocopherol- $\beta$-carotene (ATBC) and the $\beta$-carotene and Retinol Efficacy Trial (CARET) showed an increased risk of lung cancer among high-risk people supplemented with high doses of $\beta$-carotene and/or $\alpha$-tocopherol [146-149]. The latest meta-analysis showed higher blood concentrations of total carotenoids, $\alpha$-carotene, $\beta$-carotene, lycopene, and retinol were inversely associated with lung cancer risk [150]. However, because of the lack of data in people who never smoked, further large scale studies stratified by smoking status are needed to rule out residual confounding by smoking.

\section{Vitamin $C$ and $E$}

Observational studies have reported that low vitamin $C$ and vitamin $\mathrm{E}$ intakes are associated with a higher prevalence of asthma. [151]. In the 2004 Cochrane database review, supplementation of vitamin $\mathrm{C}$ was not believed to have clinical benefits in people with asthma [152] although this, and later reviews were withdrawn as there were serious data errors.

Exposure to $\mathrm{O}_{3}$ results in dose dependent depletion of antioxidants vitamin $\mathrm{C}$ and $\mathrm{E}$ in the skin [153]. Antioxidant supplementation with vitamin $C$ and $E$ above the minimum dietary requirement led to attenuated nasal inflammation and partially restored antioxidant levels in asthmatic patients exposed to high levels of $\mathrm{O}_{3}$ [154]. A meta-analysis of 24 observational studies in children and adults found lower dietary intake (but not serum level) of vitamin $\mathrm{E}$ was also significantly associated with increased asthma severity [155]. A review of 15 observational studies (including 3 birth cohorts), suggested that the evidence linking low vitamin $\mathrm{E}$ to asthma development was methodologically weak but sufficiently supportive of a potential effect warranting follow-up in clinical trials [156].

A RCT found no effect of vitamin E supplementation (500 $\mathrm{mg} /$ day) for six weeks on airway responsiveness in 72 British adults with asthma [157]. A second RCT found no effect of an antioxidant supplement (containing $\beta$-carotene, vitamin $C$ and vitamin $E$ ) on plasma F2isoprostanes, exhaled nitric oxide (NO) or peripheral blood mononuclear cell (PBMC) immune responses in 54 allergic adults [158]. In contrast to these negative results, four RCTs reported that vitamin E-containing antioxidants reduce $\mathrm{O}_{3}$-induced bronchoconstriction in subjects with $[159,160]$ and without $[161,162]$ asthma, suggesting potential protective effects of vitamin $\mathrm{E}$ against the detrimental effects of $\mathrm{O}_{3}$. A study in children looked at total antioxidant intake and asthma rates, and there appeared to be a link between higher antioxidant intake (total antioxidant capacity) and diminished sensitivity to inhaled allergens. Children in areas of low traffic pollution displayed a stronger association between sensitivity to allergens and antioxidant capacity [163]. In people with exercise induced asthma, vitamin $\mathrm{C}$ and Vitamin $\mathrm{E}$ supplement aided recovery by improving flow rates [164]. A London based bidirectional case crossover study looked at whether individual plasma antioxidant concentrations (uric acid and vitamins $\mathrm{C}, \mathrm{A}$, and $\mathrm{E}$ ) and 10 antioxidant genes could modify the response to PM with respect to hospital admissions for COPD or asthma. Two hundred and thirty four admissions were recorded and the level of PM10 was noted 14 days before and after each event. Combined admission rates were related to a $10 \mu \mathrm{g} / \mathrm{m}$ increase in PM10. Serum vitamin $\mathrm{C}$ modified the effect of PM10 on asthma/COPD exacerbations. A similar (although weaker) influence was observed for low levels of uric acid and vitamin E, whereas vitamin A showed no effect modification [165].

In terms of cancer, one team demonstrated that vitamin $E$ intake is a protective factor against lung cancer [166] whereas other studies suggested vitamin $E$ intake has no effect on lung cancer [167-169]. Moreover, a different study showed that vitamin $\mathrm{E}$ intake increased the risk of lung cancer [170]. In a meta-analysis of 9 prospective cohort studies of vitamin $\mathrm{E}$ and lung cancer from 1955-2015 found that for every $2 \mathrm{mg} / \mathrm{d}$ increase in dietary vitamin $\mathrm{E}$ intake, the risk of lung cancer decreased by $5 \%$ [171]. A later single prospective cohort study in Japan found that vitamin $\mathrm{C}$ and $\mathrm{E}$ intake had no effect on lung cancer risk [172].

\section{Vitamin D}

Vitamin D is key to the metabolism of calcium and phosphorus. In adults with Asthma, normal vitamin D levels correlated with improved asthma control and 
therefore supplementation may play a role in uncontrolled asthmatics with vitamin D deficiency [173].

Irrespective of the threshold used, in a US cohort, reduced serum or plasma vitamin $\mathrm{D}$ concentrations are commonly detected in children and adults particularly in subgroups at high risk for asthma or asthma morbidity [174, 175].

Three population-based studies (two cross-sectional $[174,176]$ and one longitudinal [177] showed an association between reduced serum vitamin D concentrations and severe disease exacerbations or core measures (eg, hospitalisations) of severe exacerbations in Costa Rican, North American, and Puerto Rican children with asthma. In the most recent of these studies, [174] vitamin D insufficiency or deficiency (a serum 25[OH] D concentration $<30 \mathrm{ng} / \mathrm{mL}$ ) was associated with increased odds of one or more severe asthma exacerbations in the previous year even in non-atopic children. This suggests that vitamin D affects the risk of severe asthma exacerbations through mechanisms other than regulation of allergic immune responses. Reduced vitamin D concentrations are also associated with increased airway smooth muscle mass, decreased lung function, and worse disease control in children with severe, therapy-resistant asthma [178]. A Cochrane database systematic review was undertaken on vitamin $\mathrm{D}$ and asthma. Meta-analysis of a modest number of trials in people with predominantly mild to moderate asthma suggests that vitamin D is likely to reduce both the risk of severe asthma exacerbation and healthcare use [179].

The latest dose -response meta-analysis of 17 prospective cohort studies found the highest circulating 25hydroxyvitamin $\mathrm{D}$ was associated with decreased lung cancer risk [180]. Another meta-analysis of 22 studies found that high vitamin $\mathrm{D}$ (or calcium) intake and serum $25(\mathrm{OH}) \mathrm{D}$ levels correlate with lower lung cancer risk and better prognosis [181].

\section{Curcumin}

The phytochemical curcumin, from turmeric, has been found to be a potent anti-inflammatory agent, and has been studied in regards to its anti-tumour, antifungal and antioxidant properties [182]. Animal models have demonstrated that curcumin is a potent anti-inflammatory agent in the lungs [183] and that it may also protect against pulmonary fibrosis [184]. A number of studies have suggested that curcumin may have some protective role against the DNA damage caused by arsenic $[185,186]$. In a pre-clinical renal cancer study, addition of curcumin to cancer cells exhibited a strong potential for protection against diesel exhaust and cisplatin-induced cytotoxicity [187]. Preclinical trials have also shown that curcumin inhibited POP associated cellular and DNA damage [188, 189].
It has also reversed nicotine induced liver toxicity in an animal study [190].

Pre-clinical studies have shown that curcumin can prevent cadmium-induced IL- 6 and IL- 8 inflammatory secretion by human airway epithelial cells. Cadmium $(\mathrm{Cd})$ is a toxic metal present in the environment and its inhalation can lead to pulmonary disease including lung cancer and COPD. Curcumin could therefore potentially be used to prevent airway inflammation due to cadmium inhalation [191]. An animal model investigated the effect of Cadmium $\left(\mathrm{CdCl}_{2}\right)$-polluted drinking water $\left(40 \mathrm{mg} \mathrm{CdCl}_{2} / \mathrm{L}\right)$ on the level of tumour necrosis factor- alpha (TNF- $\alpha$ ) and IL- 6 and found a preventative action of curcumin against $\mathrm{Cd}$ toxicity [192].

Specifically in COPD, curcumin has been shown in animal models to have a beneficial effect in smooth muscle cells and improve the mean pulmonary artery pressure and right ventricular myocardial infarction (RVMI) through stimulating the suppressor of cytokine signalling (SOCS) -3/JAK2/STAT signalling pathways [193]. In another model, curcumin was shown to suppress chemokines and affect corticosteroid sensitivity in COPD through modulating Histone deacetylase 2 (HDAC2) expression and its effect on histone modification [194]. Another animal model showed that curcumin attenuates alveolar epithelial injury in COPD, which may be partially due to the downregulation of Protein 66 homologous- collagen homologue (p66Shc) [195]. In a randomised, double blinded, parallel group study in patients with mild COPD and raised LDL cholesterol, 90mg curcumin was found to reduce the $\alpha 1$-antitrypsin-low-density lipoprotein (AT-LDL) complex, thus reducing risk of future cardiovascular events [196].

In other patients, a population based study of 2478 people found that people taking dietary curcumin through eating curry had better pulmonary function. The mean adjusted $\mathrm{FEV}_{1}$ associated with curry intake was $9.2 \%$ higher among current smokers, $10.3 \%$ higher among past smokers, and $1.5 \%$ higher among nonsmokers [197]. In 89 patients who had poor pulmonary function due to sulphur mustard, curcumin $(1500 \mathrm{mg} /$ day) + piperine $(15 \mathrm{mg} /$ day $)$ or a placebo were given for 4 weeks. The active supplement reduced systemic oxidative stress and clinical symptoms, and also improved health related quality of life [198].

The anti-cancer effects of curcumin against lung cancer have been investigated in vitro and in vivo xenograft mouse models. The key pathways appear to be downregulation of NF- $\mathrm{kB}$, modulation of miRNA pathways with inhibition of caspase-3 as well as inhibition of PI3K/ AKT pathways. In addition curcumin can act both as a chemo- and radio-sensitizing agent in lung cancer [199]. 


\section{$N$-acetylcysteine}

$\mathrm{N}$-acetylcysteine (NAC) supplementation has been shown to attenuate airway responsiveness by $42 \%$ in individuals with airway hyper-responsiveness following inhalation of diesel exhaust compared with filtered air [200] and a pre-clinical study demonstrated N-acetyl-Lcysteine supplementation in smoke exposed rats showed antioxidant protective effects [201]. A meta-analysis and systematic review found long-term NAC therapy may reduce risk of patients COPD exacerbation [202]. An exvivo study found that NAC reduced COPD exacerbation induced by lipopolysaccharide (LPS) [203]. Supplementation of NAC, $600 \mathrm{mg}$ once a day and a 20 minute daily walk in addition to regular treatment improved quality of life in stable COPD patients [204]. However in another trial, treatment with NAC elevated plasma glutathione but did not modulate central or peripheral components of the $\mathrm{O}_{2}$ transport pathway and did not therefore improve exercise tolerance in patients with mild COPD [205]. There is little evidence of any benefits such as reducing lung cancer risk.

\section{Fats}

Omega-3 oils (or n-3 polyunsaturated fats-PUFAs) have received much attention due to their ability to reduce inflammation, and for its anti-coagulant properties, thus reducing risk of cardiovascular diseases. Two randomised controlled studies have investigated early life fish oil dietary supplementation in relation to asthma outcomes in children at high risk of atopic disease (at least one parent or sibling had atopy with or without asthma). In a study, powered only to detect differences in cord blood, maternal dietary fish oil supplementation during pregnancy was associated with reduced cytokine release from allergen stimulated cord blood mononuclear cells. However, effects on clinical outcomes at one year, in relation to atopic eczema, wheeze and cough, were marginal [206] In a second study, fish oil supplementation started in early infancy with or without additional house dust mite avoidance, was associated with a significant reduction in wheeze at 18 months of age. By five years of age fish oil supplementation was not associated with effects on asthma or other atopic diseases [207]. In the absence of any evidence of benefit from the use of fish oil supplementation in pregnancy, the British Thoracic Society SIGN 2016 guidelines do not recommend it as a strategy for primary prevention of childhood asthma [208].

There are recent studies which use omega-3 oils to combat the effects of pollution. Animal models of fine particle matter pollution, demonstrated that omega- 3 oils prevented and improve inflammation caused by these fine particles [209] with a further pre-clinical study showing that omega- 3 oils reduced the oxidative damage in the intestines after heavy metals ingestion [210].

For the early and milder forms of allergic asthma, dietary supplementation with long-chain polyunsaturated fatty acids (LCPUFA), predominantly fish oil-associated eicosapentaenoic (C20:5 $\omega-3)$ and docosahexaenoic acid (C22:6 $\omega-3)$, and distinct crop oil-derived fatty acids have been proposed to provide a sustainable treatment strategy [211, 212]. C20:5 and C22:6 $\omega-3$ fatty acids inhibit cyclooxygenase (COX) activity and decrease eicosanoid synthesis from amino acids. [213]. They also suppress immunoglobulin (Ig) E production and thereby reduce airway inflammation and bronchoconstriction in asthma [214]. In 2002 a Cochrane database review concluded that there was insufficient evidence to recommend fish oil supplementation for the treatment of asthma [215].

In addition to immune-controlling prostaglandins, leukotrienes, and thromboxanes, specialised mediators, such as lipoxins, resolvins, protectins, and maresins are metabolised from different LCPUFA, which actively resolve inflammation. Where people with asthma are allergic to pollutants and other allergens, omega- 3 and some omega 6 oils also act to reduce inflammation, rebuilding fatty acid homeostasis in cellular membranes, modifying eicosanoid metabolic pathways, thus reducing clinical symptoms [216, 217]. Most recently, an animal study compared the effects of olive oil, coconut oil and fish oil. Although fish oil protected against $\mathrm{O} 3$ induced vascular damage, it increased pulmonary injury/inflammation and impaired lipid transport mechanisms [218].

A Mediterranean diet has long been suggested as the most 'healthy' diet to follow and its health benefits are largely attributed to the content of fibre, antioxidants, protein, and moderate amounts of fatpredominantly from mono-unsaturated (MUFA) and omega-3 PUFA. Airway inflammation during asthma may be modulated by dietary intake [144, 219-221]. Fruit, vegetables and their antioxidants may lower airway inflammation [144, 220]. Fruit and vegetable intake was inversely associated with IL- 8 protein in nasal lavage of asthmatic children [220]. The Mediterranean diet does offer some protection against the effects of tobacco smoke in smokers and passive smokers [222].

In contrast, high fat intake comprising of a low intake of n-3PUFAs with a corresponding increase in intake of $n$-6PUFAs is characteristic of the Western diet, can cause an increase in airway inflammation. This change has been linked to increasing rates of allergic disease and asthma [151]. Consumption of a high-fat mixed meal has been shown to increase sputum neutrophils 4 $\mathrm{h}$ post-meal in patients with asthma [223], as well as activation of a number of genes in sputum involved in 
"immune system processes", such as TLR4, indicating an increase in airway inflammation [221]. Reduction of dietary saturated fat intake was associated with a reduction in neutrophilic airway inflammation in asthmatics [222]. In adults with severe asthma, higher fat and lower fibre intakes have been associated with increased eosinophilic airway inflammation [219].

In a COPD randomised placebo controlled trial of 86 patients, an omega-3, vitamin D and leucine supplement drink was given to half the group for 4 months alongside high intensity training, whilst the other half undertook the exercise alone. The population had moderate airflow limitation, low diffusion capacity, normal protein intake, low plasma vitamin $\mathrm{D}$, and docosahexaenoic acid. There were significant differences after 4 months favouring the supplement group for body mass, plasma vitamin D, eicosapentaenoic acid, docosahexaenoic acid and number of steps [224].In a meta-analysis of 8 prospective cohort studies looking at PUFA and lung cancer risk, the team concluded that PUFA intake had little or no effect on lung cancer risk. PUFA intake might play a small role in lung cancer prevention in women, but this is unclear [225].

\section{Choline}

Choline is a lipotropic agent involved in several biological functions (eg, neurotransmitter production, signalling lipids, and components of structural membranes) , and as a methyl group donor [226]. Dietary sources of choline include meat, liver, eggs, poultry, fish and shellfish, peanuts, and cauliflower. Choline deficiency is associated with neurological disorders, cardiovascular diseases, and inflammation [227].

Intranasal or oral administration of choline has been shown to reduce the number of eosinophils and reactive oxidant species in bronchoalveolar lavage fluid in a murine model of allergic airway disease [228]. In human studies, 76 asthma patients were recruited and treated with a choline supplement (1500 mg twice) or standard pharmacotherapy for 6 months in two groups. The patients were evaluated by clinical, immunologic and biochemical parameters. The treatment with choline showed significant reduction in symptom/drug score and improvement in $\mathrm{FEV}_{1}$ compared to baseline or standard pharmacotherapy. Choline therapy significantly reduced IL-4, IL-5 and TNF-alpha level as compared to baseline or standard pharmacotherapy after 6 months $(p<0.01)$. Blood eosinophil count and total IgE levels were reduced in both of the treatment groups. [229]. In a cross-sectional survey that enrolled 1514 men and 1528 women with no history of cardiovascular disease (the ATTICA Study), fasting blood samples were collected and inflammatory markers were measured.
Compared with the lowest tertile of choline intake $(<250$ $\mathrm{mg} / \mathrm{d}$ ), participants who consumed $>310 \mathrm{mg} / \mathrm{d}$ had, on average, $22 \%$ lower concentrations of $\mathrm{C}$-reactive protein $(P<0.05), 26 \%$ lower concentrations of IL-6 $(P<0.05)$, and $6 \%$ lower concentrations of tumour necrosis factoralpha $(P<0.01)$. These findings were independent of various sociodemographic, lifestyle, and clinical characteristics of the participants [230]. This suggests that choline might attenuate allergic inflammation in general and airway inflammation in particular.

\section{Dietary recommendations}

Dietary recommendations from the British Thoracic Society and the Scottish Intercollegiate Guidelines Network, 2016 [208]:

- Weight reduction is recommended in obese patients to promote general health and to reduce subsequent respiratory symptoms consistent with asthma.

(Grade C).

- Obese and overweight children should be offered weight-loss programmes to reduce the likelihood of respiratory symptoms suggestive of asthma (Grade C).

- Weight-loss interventions (including dietary and exercise-based programmes) can be considered for overweight and obese adults and children with asthma to improve asthma control (Grade B).

Unfortunately, despite the evidence we present there are no official recommendations for using diet or supplements to help prevent COPD and lung cancer.

\section{Conclusion}

There is increasing evidence to suggest that carotenoids, vitamin $\mathrm{D}$ and vitamin $\mathrm{E}$ help protect against pollution damage which can trigger asthma, COPD and lung cancer initiation. Vitamin C, curcumin, choline and omega-3 fatty acids may also have a protective role. The Mediterranean diet appears to be of benefit to the airways, but there is no evidence of benefit in protecting against air pollution, except for tobacco smoke. Undoubtedly robust randomised studies are required however it is very difficult to design such studies due to the confounding factors of diet, obesity, co-morbid illness, medication and environmental exposure. Whilst such studies are being designed it would seem appropriate to consider making dietary recommendations and consider the role of appropriate supplementation in predisposed/at-risk individuals. Novel approaches to the mitigation of global chronic respiratory disease burden are urgently required.

\section{Abbreviations}

AhR: Aryl hydrocarbon receptors; AT-LDL: a1-antitrypsin-low-density lipoprotein; C20:5 w-3: Eicosapentaenoic; C22:6 w-3: Docosahexaenoic acid; Cd: Cadmium; COPD: Chronic obstructive pulmonary disease; 
COX: Cyclooxygenase; FEV 1 : Forced expiratory volume; FVC: Forced vital capacity; HDAC2: Histone deacetylase 2; Ig: Immunoglobulin; IL: Interleukin; LCPUFA: Long-chain polyunsaturated fatty acids; LPS: Lipopolysaccharide; MUFA: Monounsaturated fatty acids; NAC: N-acetylcysteine; $\mathrm{NO}_{2}$ : Nitrogen dioxide; O3: Ground level ozone; p66Shc: Protein 66 Src homologouscollagen homologue; PAHs: Polycyclic aromatic hydrocarbons; PBDEs: Polybrominateddiphenyl ethers; PBMC: Peripheral blood mononuclear cell; PCBs: Polychlorinated biphenyls; PM: Particulate matter; POPs: Persistent organic pollutants; RCT: Randomised controlled trial; ROS: Reactive oxygen species; RVMI: Right ventricular myocardial infarction; $\mathrm{SO}_{2}$ : Sulphur dioxide; SOCS: Suppressor of cytokine signalling; Th: T-helper; TNF-a: Tumour necrosis factor- alpha; UFP: Ultrafine particles; WHO: World Health Organisation

\section{Authors' contributions}

TW performed the search and initial draft of review. All authors contributed to draft amendments and approved the final manuscript.

\section{Competing interests}

The authors declare they have no competing interests. MC and TW act as medical and nutritional advisors to a supplements company ProfBiotics ${ }^{T M}$

\section{Publisher's Note}

Springer Nature remains neutral with regard to jurisdictional claims in published maps and institutional affiliations.

\section{Author details}

${ }^{1}$ Centre for Gastroenterology, Royal Free Hospital, London NW3 2QG, UK. ${ }^{2}$ UCL Respiratory, University College London, London, UK. ${ }^{3}$ Department of Medicine, Royal Free Hospital, London, UK.

\section{Received: 12 December 2017 Accepted: 19 April 2018}

\section{Published online: 02 May 2018}

\section{References}

1. World Health Organisation. Media Centre. http://www.who.int/mediacentre/ news/releases/2014/air-pollution/en/. Accessed 6 Feb 2018.

2. Krutmann J, Liu W, Li L, Pan X, Crawford M, Sore G, et al. Pollution and skin: from epidemiological and mechanistic studies to clinical implications. J Dermatol Sci. 2014;76:163-8. https://doi.org/10.1016/j.jdermsci.2014.08.008 .

3. Guan W-J, Zheng X-Y, Chung KF, Zhong N-S. Impact of air pollution on the burden of chronic respiratory diseases in China: time for urgent action. Lancet. 2016;388:1939-51. https://doi.org/10.1016/S0140-6736(16)31597-5.

4. Ahn K. The role of air pollutants in atopic dermatitis. J. Allergy Clin. Immunol. 2014;134:993-9. https://doi.org/10.1016/j.jaci.2014.09.023.

5. Kim EH, Kim S, Lee JH, Kim J, Han Y, Kim YM, et al. Indoor air pollution aggravates symptoms of atopic dermatitis in children. PLoS One. 2015;10: e0119501. https://doi.org/10.1371/journal.pone.0119501.

6. Lee JH, Lee HS, Park MR, Lee SW, Kim EH, Cho JB, et al. Relationship between indoor air pollutant levels and residential environment in children with atopic dermatitis. Ann. Allergy Asthma Immunol. 2014;6:517-24. https://doi.org/10.4168/aair.2014.6.6.517.

7. Annesi-Maesano I, Moreau D, Caillaudc D, Lavaudd FO, Moullece YL, et al. Residential proximity fine particles related to allergic sensitisation and asthma in primary school children. Respir. Med. 2007;101:1721-9. https://doi. org/10.1016/j.rmed.2007.02.022.

8. Brauer M, Hoek G, Smit HA, Jongste JCD, Gerritsen J, Postmae DS, et al. Ai pollution and development of asthma, allergy and infections in a birth cohort. Eur. Respir. J. 2007;29:879-88. https://doi.org/10.1183/09031936. 00083406 .

9. Szyszkowicz M, Kousha T, Valacchi G. Ambient air pollution and emergency department visits for skin conditions. Glob. Dermatol. 2016;3:323-9. https:// doi.org/10.15761/GOD.1000184.

10. Kampa M, Castanas E. Human health effects of air pollution. Environ Pollut. 2008;151:362-7. https://doi.org/10.1016/j.envpol.2007.06.012.

11. DeVries R, Kriebel D, Sama S. Low level air pollution and exacerbation of existing copd: a case crossover analysis. Environ Health. 2016;15:98. https:// doi.org/10.1186/s12940-016-0179-z.

12. Friedman MS, Powell KE, Hutwagner L, Graham LM, Teague WG. Impact of changes in transportation and commuting behaviors during the 1996 Summer Olympic Games in Atlanta on air quality and childhood asthma. JAMA. 2001;285:897-905. https://doi.org/10.1001/jama.285.7.897.
13. O'Connor GT, Neas L, Vaughn B, Kattan M, Mitchell H, Crain EF, et al. Acute respiratory health effects of air pollution on children with asthma in US inner cities. J Allergy Clin Immunol. 2008;121:1133-9. https://doi.org/10. 1016/j.jaci.2008.02.020.

14. Weinmayr G, Romeo E, De Sario M, Weiland SK, Forastiere F. Short-term effects of PM10 and NO2 on respiratory health among children with asthma or asthma-like symptoms: a systematic review and meta-analysis. Environ Health Perspect. 2010;118:449-57. https://doi.org/10.1289/ehp.0900844.

15. Health Effects Institute. A Special Report of the Institute's Panel on the Health Effects of Traffic-Related Air Pollution 2010. https://www. healtheffects.org/publication/traffic-related-air-pollution-critical-reviewliterature-emissions-exposure-and-health. Accessed 6 Feb 2018.

16. Dong G-H, Chen T, Liu M-M, Wang D, Ma YN, Ren WH, et al. Gender differences and effect of air pollution on asthma in children with and without allergic predisposition: northeast Chinese children health study. PLoS One. 2011;6:e22470. https://doi.org/10.1371/journal.pone.0022470.

17. Nishimura KK, Galanter JM, Roth LA, Oh SS, Thakur N, Nguyen EA, et al. Early-life air pollution and asthma risk in minority children. The GALA ॥ and SAGE II studies. Am J Respir Crit Care Med. 2013;188:309-18. https://doi.org/10.1164/rccm.201302-0264OC.

18. Jacquemin B, Sunyer J, Forsberg B, Aguilera I, Briggs D, García-Esteban R, et al, Home outdoor NO2 and new-onset of self-reported asthma in adults. Epidemiology. 2009;20:119-26. https://doi.org/10.1097/EDE.0b013e3181886e76.

19. Jerrett M, Shankardass K, Berhane K, Gauderman WJ, Künzli N, Avol E, et al. Traffic-related air pollution and asthma onset in children: a prospective cohort study with individual exposure measurement. Environ Health Perspect. 2008;116:1433-8. https://doi.org/10.1289/ehp.10968.

20. McConnell $R$, Islam $T$, Shankardass $K$, Jerrett M, Lurmann F, Gilliland $F$, et al. Childhood incident asthma and traffic-related air pollution at home and school. Environ Health Perspect. 2010:118:1021-6. https://doi. org/10.1289/ehp.0901232

21. Zhou C, Baiz N, Zhang T, Banerjee S, Annesi-Maesano I. Modifiable exposures to air pollutants related to asthma phenotypes in the first year of life in children of the EDEN mother-child cohort study. BMC Public Health 2013;13:506. https://doi.org/10.1186/1471-2458-13-506.

22. Carlsten C, Dybuncio A, Becker A, Chan-Yeung M, Brauer M. Traffic-related air pollution and incident asthma in a high-risk birth cohort. Occup Environ Med. 2011;68:291-5. https://doi.org/10.1136/oem.2010.055152.

23. Clark NA, Demers PA, Karr CJ, Koehoorn M, Lencar C, Tamburic L, et al. Effect of early life exposure to air pollution on development of childhood asthma. Environ Health Perspect. 2010;118:284-90. https://doi. org/10.1289/ehp.0900916.

24. Kunzli N, Bridevaux P-O, Liu L-JS, Garcia-Esteban R, Schindler C, Gerbase MW, et al. Traffic-related air pollution correlates with adult-onset asthma among never-smokers. Thorax. 2009:64:664-70. https://doi.org/ 10.1136/thx.2008.110031.

25. Modig L, Toren K, Janson C, Jarvholm B, Forsberg B. Vehicle exhaust outside the home and onset of asthma among adults. Eur Respir J. 2009;33:1261-7. https://doi.org/10.1183/09031936.00101108.

26. Anderson HR, Favarato G, Atkinson RW. Long-term exposure to air pollution and the incidence of asthma: meta-analysis of cohort studies. Air Qual Atmos Health. 2013;6:47-56. https://doi.org/10.1007/s11869-011-0144-5.

27. Loomis D, Grosse Y, Lauby-Secretan B, El Ghissassi F, Bouvard V. Benbrahim-Tallaa Let al. The carcinogenicity of outdoor air pollution. Lancet Oncol. 2013:4:1262-3.

28. World Health Organisation. Media Centre. Ambient (outdoor) air quality and health. 2016. http://www.who.int/mediacentre/factsheets/fs313/en/ Accessed 4 Apr 2017.

29. Kumar P. Role of Plastics on Human Health. Indian J Pediatr. 2018. https:// doi.org/10.1007/s12098-017-2595-7.

30. Tsai MJ, Kuo PL, Ko YC. The association between phthalate exposure and asthma. Kaohsiung J Med Sci. 2012;28:28-36. https://doi.org/10. 1016/j.kjms.2012.05.007

31. Jaakkola JJ, Oie L, Nafstad P, Botten G, Samuelsen SO, Magnus P. Interior surface materials in the home and the development of bronchial obstruction in young children in Oslo, Norway. Am. J. Public Health. 1999; 89:188-92. https://doi.org/10.2105/AJPH.89.2.188

32. Jaakkola JJ, Knight TL. The role of exposure to phthalates from polyvinyl chloride products in the development of asthma and allergies: A systematic review and meta-analysis. Environ. Health Perspect. 2008:116:845-53. https:// doi.org/10.1289/ehp.10846. 
33. Jaakkola JJ, Verkasalo PK, Jaakkola N. Plastic wall materials in the home and respiratory health in young children. Am. J. Public Health. 2000;90:797-9. https://doi.org/10.2105/AJPH.90.5.797.

34. Oie L, Nafstad P, Botten G, Magnus P, Jaakkola JJK. Ventilation in homes and bronchial obstruction in young children. Epidemiology. 1999;10:294-9. https://doi.org/10.1097/00001648-199905000-00018.

35. Ponsonby AL, Dwyer T, Kemp A, Cochrane J, Couper D, Carmichael A. Synthetic bedding and wheeze in childhood. Epidemiology. 2003;14:37-44. https://doi.org/10.1097/00001648-200301000-00012.

36. Hoppin JA, Ulmer R, London SJ. Phthalate exposure and pulmonary function. Environ. Health Perspect. 2004;112:571-4. https://doi.org/10.1289/ehp.6564.

37. Tan C, Wang $Y$, Lin M, Wang Z, He L, Li Z, et al. Long-term high air pollution exposure induced metabolic adaptations in traffic policemen. Environ Toxicol Pharmacol. 2018;58:156-62. https://doi.org/10.1016/j.etap. 2018.01.002.

38. Ku T, Ji X, Zhang Y, Li G, Sang N, et al. Abnormal energy metabolism and tau phosphorylation in the brains of middle-aged mice in response to atmospheric PM2.5 exposure. J Environ Sci (China). 2017 62:145-153. doi: https://doi.org/10.1016/j.jes.2017.06.037. Epub 11 July 2017.

39. Møller P, Jacobsen NR, Folkmann JK, Danielsen PH, Mikkelsen L, Hemmingsen JG, et al. Role of oxidative damage in toxicity of particulates. Free Radic Res. 2010;44:1-46. https://doi.org/10.3109/10715760903300691.

40. Lodovici M, Bigagli E. Oxidative stress and air pollution exposure. J Toxicol. 2011;2011:487074. https://doi.org/10.1155/2011/487074.

41. Xu Z, Xu X, Zhong M, Hotchkiss IP, Lewandowski RP, Wagner JG, et al. Ambient particulate air pollution induces oxidative stress and alterations of mitochondria and gene expression in brown and white adipose tissues. Part Fibre Toxicol. 2011;8:20. https://doi.org/10.1186/1743-8977-8-20.

42. van Eeden SF, Tan WC, Suwa T, Mukae H, Terashima T, Fujii T, et al. Cytokines involved in the systemic inflammatory response induced by exposure to particulate matter air pollutants (PM(10)). Am J Respir Crit Care Med. 2001;164:826-30. https://doi.org/10.1164/ajrccm.164.5.2010160.

43. Gavett SH, Koren HS. The role of particulate matter in exacerbation of atopic asthma. Int Arch Allergy Immunol. 2001;124:109-12. https://doi.org/ 10.1159/000053685.

44. Tecer LH, Alagha $\mathrm{O}$, Karaca F, Tuncel G, Eldes N. Particulate matter (PM(2.5), PM(10-2.5), and PM(10)) and children's hospital admissions for asthma and respiratory diseases: a bidirectional case-crossover study. J Toxicol Environ Health A. 2008;71:512-20. https://doi.org/10.1080/15287390801907459.

45. Ling SH, van Eeden SF. Particulate matter air pollution exposure: role in the development and exacerbation of chronic obstructive pulmonary disease. Int J Chron Obstruct Pulmon Dis. 2009;4:233-43. https://doi.org/10.2147/ COPD.S5098.

46. van Eeden SF, Yeung A, Quinlam K, Hogg JC. Systemic response to ambient particulate matter: relevance to chronic obstructive pulmonary disease. Proc Am Thorac Soc. 2005;2:61-7. https://doi.org/10.1513/pats.200406-035MS.

47. de Hartog JJ, Ayres JG, Karakatsani A, Analitis A, Brink HT, Hameri K, et al. Lung function and indicators of exposure to indoor and outdoor particulate matter among asthma and COPD patients. Occup Environ Med. 2010;67:210. https://doi.org/10.1136/oem.2008.040857.

48. Kanatani KT, Ito I, Al-Delaimy WK, Adachi Y, Mathews WC, Ramsdell JW, et al. Desert dust exposure is associated with increased risk of asthma hospitalization in children. Am J Respir Crit Care Med. 2010;182:1475-81. https://doi.org/10.1164/rccm.201002-02960C.

49. He M, Ichinose T, Yoshida S, Yamamoto S, Inoue K, Takano H, et al. Asian sand dust enhances murine lung inflammation caused by Klebsiella pneumoniae. Toxicol Appl Pharmacol. 2012;258:237-47. https://doi.org/10. 1016/j.taap.2011.11.003.

50. Yeo NK, Hwang YJ, Kim ST, Kwon HJ, Jang YJ. Asian sand dust enhances rhinovirus-induced cytokine secretion and viral replication in human nasal epithelial cells. Inhal Toxicol. 2010;22(2):1038-45. https://doi.org/10.3109/ 08958378.2010.516282

51. Kim YH, Warren SH, Krantz QT, King C, Jaskot R, Preston WT, et al. Mutagenicity and Lung Toxicity of Smoldering vs. Flaming Emissions from Various Biomass Fuels: Implications for Health Effects from Wildland Fires. Environ Health Perspect. 2018;126(1):017011. https://doi. org/10.1289/EHP2200.

52. Jarvis IWH, Enlo-Scott Z, Nagy E, Mudway IS, Tetley TD, Arlt VM, et al. Genotoxicity of fine and coarse fraction ambient particulate matter in immortalised normal (TT1) and cancer-derived (A549) alveolar epithelial cells. Environ Mol Mutagen. 2018; https://doi.org/10.1002/em.22166.
53. Liao $Y, X u$ L, Lin $X$, Hao YT. Temporal Trend in Lung Cancer Burden Attributed to Ambient Fine Particulate Matter in Guangzhou, China. Biomed Environ Sci. 2017;30(10):708-17. https://doi.org/10.3967/ bes2017.096.

54. Gharibvand L, Shavlik D, Ghamsary M, Beeson WL, Soret S, Knutsen R, Knutsen SF. The association between ambient fine particulate air pollution and lung cancer incidence: results from the AHSMOG-2 study. Environ Health Perspect. 2017;125:378-84. https://doi.org/10.1289/EHP124

55. Valavanidis A, Vlachogianni T, Fiotakis K, Loridas S. Pulmonary oxidative stress, inflammation and cancer: respirable particulate matter, fibrous dusts and ozone as major causes of lung carcinogenesis through reactive oxygen species mechanisms. Int J Environ Res Public Health. 2013;10:3886-907. https://doi.org/10.3390/ijerph10093886.

56. Hertz-Picciotto I, Baker RJ, Yap PS, Dostál M, Joad JP, Lipsett M, et al. Early childhood lower respiratory illness and air pollution. Environ. Health Perspect. 2007;115(0):1510-8. https://doi.org/10.1289/ehp.9617.

57. Jedrychowski W, Galas A, Pac A, Flak E, Camman D, Rauh V, et al. Prenatal ambient air exposure to polycyclic aromatic hydrocarbons and the occurrence of respiratory symptoms over the first year of life. Eur. J. Epidemiol. 2005;20:775-82. https://doi.org/10.1007/s10654-005-1048-1.

58. Choi Y-H, Kim JH, Hong Y-C. CYP1A1 genetic polymorphism and polycyclic aromatic hydrocarbons on pulmonary function in the elderly: haplotypebased approach for gene-environment interaction. Toxicol. Lett. 2013;221: 185-90. https://doi.org/10.1016/j.toxlet.2013.06.229.

59. Barraza-Villarreal A, Escamilla-Nuñez MC, Schilmann A, Hernandez-Cadena L, $L i$, Romanoff $L$, et al. Lung function, airway inflammation, and polycyclic aromatic hydrocarbons exposure in Mexican schoolchildren: a pilot study. Occup. Environ. Med. 2014;56:415-9. https://doi.org/10.1037/emo0000122.

60. Jedrychowski WA, Perera FP, Maugeri U, Majewska R, Mroz E, Flak E, et al. Long term effects of prenatal and postnatal airborne PAH exposures on ventilatory lung function of non-asthmatic preadolescent children. Prospective birth cohort study in Krakow. Sci. Total Environ. 2015;502:502-9. https://doi.org/10.1016/j.scitotenv.2014.09.051.

61. Padula AM, Balmes JR, Eisen EA, Mann J, Noth EM, Lurmann FW, et al. Ambient polycyclic aromatic hydrocarbons and pulmonary function in children. J. Expo. Sci. Environ. Epidemiol. 2015;25:295-302. doi.org/10. 1038/jes.2014.42

62. Zhou $Y$, Sun $H$, Xie J, Song $Y$, Liu $Y$, Huang $X$, et al. Urinary polycyclic aromatic hydrocarbon metabolites and altered lung function in Wuhan, China. Am. J. Respir. Crit. Care Med. 2016;193:835-46. https://doi.org/10. 1164/rccm.201412-22790C.

63. Wang S, Bai Y, Deng Q, Chen Z, Dai J, Li X, et al. Polycyclic aromatic hydrocarbons exposure and lung function decline among coke-oven workers: a four-year follow-up study. Environ. Res. 2016;150:14-22. https://doi.org/10. 1016/j.envres.2016.05.025.

64. Bauer AK, Velmurugan K, Plöttner S, Siegrist KJ, Romo D, Welge P, et al. Environmentally prevalent polycyclic aromatic hydrocarbons can elicit cocarcinogenic properties in an in vitro murine lung epithelial cell model. Arch Toxicol. 2017; https://doi.org/10.1007/s00204-017-2124-5.

65. Bell ML, Zanobetti A, Dominici F. Who is more affected by ozone pollution? A systematic review and meta-analysis. Am J Epidemiol. 2014;180:15-28. https://doi.org/10.1093/aje/kwu115.

66. Gryparis A, Forsberg B, Katsouyanni K, Analitis A, Touloumi G, Schwartz J, et al. Acute effects of ozone on mortality from the "air pollution and health: a European approach" project. Am J Respir Crit Care Med. 2004;170:1080-7. https://doi.org/10.1164/rccm.200403-3330C.

67. Levy Jl, Chemerynski SM, Sarnat JA. Ozone exposure and mortality: an empiric bayes metaregression analysis. Epidemiology. 2005;16:458-68. https://doi.org/10.1097/01.ede.0000165820.08301.b3.

68. Stieb DM, Szyszkowicz M, Rowe BH, Leech JA. Air pollution and emergency department visits for cardiac and respiratory conditions: a multi-city time-series analysis. Environ Health. 2009;8:25. https:/doi.org/10.1186/1476-069X-8-25.

69. Jerrett M, Burnett RT, Pope CA, Ito K, Thurston G, Krewski D, et al. Long-term ozone exposure and mortality. N Engl J Med. 2009;360:1085-95. https://doi. org/10.1056/NEJMoa0803894.

70. Zanobetti A, Schwartz J. Ozone and survival in four cohorts with potentially predisposing diseases. Am J Respir Crit Care Med. 2011;184:836-41. https:// doi.org/10.1164/rccm.201102-02270C.

71. Hystad P, Demers PA, Johnson KC, Carpiano RM, Brauer M. Long-term residential exposure to air pollution and lung cancer risk. Epidemiology. 2013;24:762-72. https://doi.org/10.1097/EDE.0b013e3182949ae7. 
72. Cakmak S, Hebbern C, Pinault L, Lavigne E, Vanos J, Crouse DL, et al. Associations between long-term PM2.5 and ozone exposure and mortality in the Canadian Census Health and Environment Cohort (CANCHEC), by spatial synoptic classification zone. Environ Int. 2018;111:200-11. https://doi. org/10.1016/j.envint.2017.11.030.

73. Knibbs LD, Hewson MG, Bechle MJ, Marshall JD, Barnett AG. A national satellite-based land-use regression model for air pollution exposure assessment in Australia. Environ. Res. 2014;135:204-11. https://doi.org/10. 1016/j.envres.2014.09.011.

74. Richter A, Burrows JP, Nuss H, Granier C, Niemeier U. Increase in tropospheric nitrogen dioxide over China observed from space. Nature. 2005;437:129-32. https://doi.org/10.1038/nature04092.

75. Faustini A, Rapp R, Forastiere F. Nitrogen dioxide and mortality: Review and meta-analysis of long-term studies. Eur. Respir. J. 2014;44:744-53. https://doi. org/10.1183/09031936.00114713.

76. Dadvand P, Nieuwenhuijsen MJ, Agusti A, de Batlle J, Benet M, Beelen R, et al. Air pollution and biomarkers of systemic inflammation and tissue repair in COPD patients. Eur. Respir. J. 2014;44:603-13. https://doi.org/10.1183/ 09031936.00168813.

77. Liu F, Zhao Y, Liu YQ, Liu Y, Sun J, Huang MM, et al. Asthma and asthma related symptoms in Chinese children in relation to indoor and outdoor environmental factors: the Seven North eastern Cities (SNEC) study. Sci Total Environ. 2014;497-498:10-7. https://doi.org/10.1016/j.scitotenv.2014.07.096.

78. Dai Q, Min X, Weng M. A review of polychlorinated biphenyls (PCBs) pollution in indoor air environment. J Air Waste Manag Assoc. 2016;66(10): 941-50. https://doi.org/10.1080/10962247.2016.1184193.

79. Priha E, Hellman S, Sorvari J. PCB contamination from polysulphide sealants in residential areas_Exposure and risk assessment. Chemosphere. 2005;594: 537-43. https://doi.org/10.1016/j.chemosphere.2005.01.010.

80. Guo J, Capozzi SL, Kraeutler TM, Rodenburg LA. Global distribution and local impacts of inadvertently generated polychlorinated biphenyls in pigments. Environ. Sci. Technol. 2014;48:8573-80. https://doi.org/10.1021/es502291b.

81. Hu D, Hornbuckle KC. Inadvertent polychlorinated biphenyls in commercial paint pigments. Environ. Sci. Technol. 2009;44:2822-7. https://doi.org/10. 1021/es902413k

82. Simcik MF, Zhang $H$, Eisenreich SJ, Franz TP. Urban contamination of the Chicago/coastal Lake Michigan atmosphere by PCBs and PAHs during AEOLOS. Environ. Sci. Technol. 1997;31:2141-7. https://doi.org/10. 1021/es9609765.

83. Wethington DM, Hornbuckle KC. Milwaukee WI as a source of atmospheric PCBs to Lake Michigan. Environ. Sci. Technol. 2005;39:57-63.

84. Bushart SP, Bush B, Barnard EL, Bott A. Volatilization of extensively dechlorinated polychlorinated biphenyls from historically contaminated sediments. Environ. Toxicol. Chem. 1998;17:1927-33.

85. Harrad S, Ren J, Hazrati S, Robson M. Chiral signatures of PCB\#s 95 and 149 in indoor air, grass, duplicate diets and human faeces. Chemosphere. 2006 63:1368-76. https://doi.org/10.1016/j.chemosphere.2005.09.027.

86. Robson M, Harrad S. Chiral PCB signatures in air and soil: Implications for atmospheric source apportionment. Environ. Sci. Technol. 2004;38(6):1662.

87. Currado GM, Harrad S. Comparison of polychlorinated biphenyl concentrations in indoor and outdoor air and the potential significance of inhalation as a human exposure pathway. Environ. Sci. Technol. 1998;32: 3043-7.

88. Harrad S, Hazrati S, Ibarra C. Concentrations of polychlorinated biphenyls in indoor air and polybrominated diphenyl ethers in indoor air and dust in Birmingham, United Kingdom: Implications for human exposure. Environ. Sci. Technol. 2006:40:4633-8.

89. Norström K, Czub G, McLachlan MS, Hu D, Thorne PS, Hornbuckle KC. External exposure and bioaccumulation of PCBs in humans living in a contaminated urban environment. Environ. Int. 2010;36:855-61. https:// doi.org/10.1016/j.envint.2009.03.005.

90. Lehmann L, Esch HL, Kirby PA, Robertson LW, Ludewig G. 4Monochlorobiphenyl (PCB3) induces mutations in the livers of transgenic Fisher 344 rats. Carcinogenesis. 2006;28:471-8. https:/doi.org/10.1093/carcin/bgl157,.

91. Li MC, Chen PC, Tsai PC, Furue M, Onozuka D, Hagihara A, et al. Mortality after exposure to polychlorinated biphenyls and polychlorinateddibenzofurans: a meta-analysis of two highly exposed cohorts. Int J Cancer. 2015;137(6):142732. https://doi.org/10.1002/ijc.29504.

92. Majkova Z, Oesterling E, Toborek M, Hennig B. Impact of nutrition on PCB toxicity. Environ Toxicol Pharmacol. 2008;25:192-6. https://doi.org/ 10.1016/j.etap.2007.10.015.
93. Ruzzin J, Petersen R, Meugnier E, Madsen L, Lock EJ, Lillefosse $H$, et al. Persistent organic pollutant exposure leads to insulin resistance syndrome. Environ Health Perspect. 2010;118:465-71. https://doi.org/10. 1289/ehp.0901321.

94. Hennig B, Toborek M, Reiterer G, et al. Nutrition modulates PCB toxicity: Implications in atherosclerosis. In: Hansen LG, Robertson LW, editors. Human and Environmental Disposition and Toxicology; 2008. p. 165-71.

95. Watkins BA, Hannon K, Ferruzzi M, Li Y. Dietary PUFA and flavonoids as deterrents for environmental pollutants. J Nutr Biochem. 2007;18:196-205. https://doi.org/10.1016/j.jnutbio.2006.12.002.

96. Ludewig G, Robertson LW. Polychlorinated biphenyls (PCBs) as initiating agents in hepatocellular carcinoma. Cancer Lett. 2013;334:46-55. https://doi. org/10.1016/j.canlet.2012.11.041.

97. Hennig B, Hammock BD, Slim R, Toborek M, Saraswathi V, Robertson LW. PCB-induced oxidative stress in endothelial cells: modulation by nutrients. Int J Hyg Environ Health. 2002;205:95-102. https://doi.org/10. 1078/1438-4639-00134.

98. Dong GH, Wang J, Zeng XW, Chen L, Qin XD, Zhou Y, et al. Interactions Between Air Pollution and Obesity on Blood Pressure and Hypertension in Chinese Children. Epidemiology. 2015;26(5):740-7. https://doi.org/10.1097/ EDE.0000000000000336.

99. Jerrett M, McConnell R, Wolch J, et al. Traffic-related air pollution and obesity formation in children: a longitudinal, multilevel analysis. Environmental Health. 2014;13:49. https://doi.org/10.1186/1476-069X-13-49.

100. Brook RD, Jerrett M, Brook JR, Bard RL, Finkelstein MM. The relationship between diabetes mellitus and traffic-related air pollution. J Occup Env Med. 2008;50:32-8. https://doi.org/10.1097/JOM.0b013e31815dba70.

101. Krämer U, Herder C, Sugiri D, Strassburger K, Schikowski T, Ranft U, Rathmann W. Traffic-related air pollution and incident type 2 diabetes: results from the SALIA cohort study. Env Heal Perspect. 2010;118:1273-9. https://doi.org/10.1289/ehp.0901689.

102. Ma YN, Zhao Y, Liu YQ, Wang D, Ren WH, Gao F, et al. Effects of indoor air pollution on asthma and asthma-related symptoms among children in Shenyang city. Zhonghua Yu Fang Yi Xue Za Zhi. 2013;47:49-54.

103. Zhao Z, Zhang Z, Wang Z, Ferm M, Liang Y, Norbäck D. Asthmatic symptoms among pupils in relation to winter indoor and outdoor air pollution in schools in Taiyuan, China. Environ Health Perspect. 2008; 116:90-7. https://doi.org/10.1289/ehp.10576.

104. Peters JM, Avol E, Navidi W, London SJ, Gauderman WJ, et al. A study of twelve Southern California communities with differing levels and types of air pollution. I. Prevalence of respiratory morbidity. Am J Respir Crit Care Med. 1999;159:760-7. https://doi.org/10.1164/ajrccm.159.3. 9804143.

105. Gehring U, Cyrys J, Sedlmeir G, Brunekreef B, Bellander T, Fischer P, et al. Trafficrelated air pollution and respiratory health during the first $2 \mathrm{yrs}$ of life. Eur Respir. 2002;J19:690-8. https://doi.org/10.1183/09031936.02.01182001.

106. Gauderman WJ, Vora H, McConnell R, Berhane K, Gilliland F, et al. Effect of exposure to traffic on lung development from 10 to 18 years of age: a cohort study. Lancet. 2007;369:571-7. https://doi.org/10.1016/S01406736(07)60037-3.

107. Rojas-Martinez R, Perez-Padilla R, Olaiz-Fernandez G, Mendoza-Alvarado $L$, Moreno-Macias $H$, et al. Lung function growth in children with longterm exposure to air pollutants in Mexico City. Am J Respir Crit Care Med. 2007;176:377-84. https://doi.org/10.1164/rccm.200510-16780C.

108. Becklake MR, Kauffmann F. Gender differences in airway behaviour over the human life span. Thorax. 1999;54:1119-38. https://doi.org/10. 1136/thx.54.12.1119.

109. Polgar G, Weng TR. The functional development of the respiratory system from the period of gestation to adulthood. Am Rev Respir Dis. 1979;120:625-95. https://doi.org/10.1164/arrd.1979.120.3.625.

110. Wong GW, Ko FW, Lau TS, Li ST, Hui D, Pang SW, et al. Temporal relationship between air pollution and hospital admissions for asthmatic children in Hong Kong. Clin Exp Allergy. 2001;31:565-9. https://doi.org/10. 1046/j.1365-2222.2001.01063.x.

111. Lee SL, Wong WHS, Lau YL. Association between air pollution and asthma admission among children in Hong Kong. Clin Exp Allergy. 2006;36:1138-46. https://doi.org/10.1111/j.1365-2222.2006.02555.x.

112. Qiu H, Yu ITS, Tian L, Wang X, Tse LA, Tam W, et al. Effects of coarse particulate matter on emergency hospital admissions for respiratory diseases: a time-series analysis in Hong Kong. Environ Health Perspect. 2012; 120:572-6. https://doi.org/10.1289/ehp.1104002. 
113. Ko FW, Tam W, Wong TW, Lai CK, Wong GW, Leung TF, et al. Effects of air pollution on asthma hospitalization rates in different age groups in Hong Kong. Clin Exp Allergy. 2007;37:1312-9. https://doi.org/10.1111/j. 1365-2222.2007.02791.x.

114. Cheng MH, Cheng CC, Chiu HF, Yang CY. Fine particulate air pollution and hospital admission for asthma: a case-crossover study in Taipei. J Toxicol Environ Health. 2014;77:1071-83. https://doi.org/10.1080/15287394.2014. 922387.

115. Zheng T, Niu S, Lu B, Fan X, Sun F, Wang J, et al. Childhood asthma in Beijing, China: a population-based case-control study. Am J Epidemiol. 2002; 156:977-83.

116. Hua J, Yin Y, Peng L, Du L, Geng F, Zhu L. Acute effects of black carbon and PM2.5 on children asthma admissions: a time-series study in a Chinese city. Sci Total Environ. 2014;481:433-8. https://doi.org/10. 1016/j.scitotenv.2014.02.070

117. Deng Q, Lu C, Norback D, Bornehag CG, Zhang Y, Liu W, et al. Early life exposure to ambient air pollution and childhood asthma in China. Environ Res. 2015;143:83-92. https://doi.org/10.1016/j.envres.2015.09.032.

118. Schultz ES, Gruzieva O, Bellander T, Bottai M, Hallberg J, Kull I, et al. Trafficrelated air pollution and lung function in children at 8 years of age: a birth cohort study. Am J Respir Crit Care Med. 2012;186:1286-91. https://doi.org/ 10.1164/rccm.201206-1045OC.

119. Das A, Krishnamurthy A, Ramshankar V, Sagar TG, Swaminathan R. The increasing challenge of never smokers with adenocarcinoma lung: Need to look beyond tobacco exposure. Indian J Cancer. 2017;54(1):172-7. https://doi.org/10.4103/ijc.IJC_33_17.

120. Pocernich $C B$, Lange $M L$, Sultana $R$, Butterfield DA. Nutritional approaches to modulate oxidative stress in Alzheimer's disease. Curr Alzheimer Res. 2011;8:452-69. https://doi.org/10.2174/ 156720511796391908

121. Ward-Caviness CK, Breitner S, Wolf K, Cyrys J, Kastenmüller G, Wang-Sattler $\mathrm{R}$, et al. Short-term NO2 exposure is associated with long-chain fatty acids in prospective cohorts from Augsburg, Germany: results from an analysis of 138 metabolites and three exposures. Int J Epidemiol. 2016:45:1528-38. https://doi.org/10.1093/ije/dyw247.

122. Caramori G, Papi A. Oxidants and asthma. Thorax. 2004;59:170-3. https://doi. org/10.1136/thorax.2002.002477.

123. Riedl MA, Nel AE. Importance of oxidative stress in the pathogenesis and treatment of asthma. Curr Opin Allergy Clin Immunol. 2008;8:49-56. https:// doi.org/10.1097/ACl.0b013e3282f3d913.

124. Katsoulis K, Kontakiotis T, Leonardopoulos I, Kotsovili A, Legakis IN, Patakas D. Serum total antioxidant status in severe exacerbation of asthma: correlation with the severity of the disease. J Asthma. 2003:40:847-54.

125. Schunemann HJ, Grant BJ, Freudenheim JL, Muti P, Browne RW, Drake JA, et al. The relation of serum levels of antioxidant vitamins $C$ and $E$, retinol and carotenoids with pulmonary function in the general population. Am J Respir Crit Care Med. 2001;163:1246-55. https://doi.org/10.1164/airccm.163.5. 2007135.

126. Ochs-Balcom HM, Grant BJ, Muti P, Sempos CT, Freudenheim JL, Browne $\mathrm{RW}$, et al. Antioxidants, oxidative stress, and pulmonary function in individuals diagnosed with asthma or COPD. Eur J Clin Nutr. 2006;60:991-9. https://doi.org/10.1038/sj.ejcn.1602410.

127. Tanumihardjo SA. Vitamin A: biomarkers of nutrition for development. Am J Clin Nutr. 2011;94:658-65. https://doi.org/10.3945/ajcn.110.005777.

128. Litonjua AA. Fat-soluble vitamins and atopic disease: what is the evidence? Proc Nutr Soc. 2012;71:67-74. https://doi.org/10.1017/\$002966511100334X.

129. Johnson E. The role of carotenoids in human health. Nutr Clin Care. 2002; 5(2):56-65.

130. Fitzpatrick AM, Teaque WG, Holguin F, Yeh M, Brown LA. Airway glutathione homeostasis is altered in children with severe asthma: evidence for oxidant stress. J Allergy Clin Immunol. 2009;12:146-52 e8. https://doi.org/10.1016/j. jaci.2008.10.047.

131. Paiva SA, Beta-carotene RRM. other carotenoids as antioxidants. J Am Coll Nutr. 1999:18:426-33.

132. Mora JR, Iwata M, von Andrian UH. Vitamin effects on the immune system: vitamins A and D take centre stage. Nat Rev Immunol. 2008:8:685-98. https://doi.org/10.1038/nri2378.

133. Benson MJ, Pino-Lagos K, Rosemblatt M, Noelle RJ. All-trans retinoic acid mediates enhanced T reg cell growth, differentiation, and gut homing in the face of high levels of co-stimulation. J Exp Med. 2007;204:1765-74. https://doi.org/10.1084/jem.20070719.
134. Sun CM, Hall JA, Blank RB, Bouladoux N, Oukka M, Mora JR, et al. Small intestine lamina propria dendritic cells promote de novo generation of Foxp3 T reg cells via retinoic acid. J Exp Med. 2007;204:1775-85. https://doi. org/10.1084/jem.20070602.

135. Mucida D, Park Y, Kim G, Turovskaya O, Scott I, Kronenberg M, et al. Reciprocal TH17 and regulatory T cell differentiation mediated by retinoic acid. Science. 2007;317:256-60. https://doi.org/10.1126/science.1145697.

136. Lovett-Racke AE, Racke MK. Retinoic acid promotes the development of Th2-like human myelin basic protein-reactive T cells. Cell Immunol. 2002;215:54-60

137. Chew BP, Park JS. Carotenoid action on the immune response. J Nutr. 2004;134:257-61.

138. Checkley, W, West, KP Jr, Wise, RA, Wu L, LeClerq SC, Khatry S et al. Supplementation with vitamin $A$ early in life and subsequent risk of asthma. Eur Respir J. 2011; 38: 1310-1319. doi: https://doi.org/10.1183/09031936. 00006911.

139. Checkley W, West KP Jr, Wise RA, Baldwin MR, Wu L, LeClerq SC et al. Maternal vitamin A supplementation and lung function in offspring. N Engl J Med. 2010;362:1784-1794. doi: https://doi.org/10.1056/NEJMoa0907441.

140. Ramsey CD, Celedon JC, Sredl DL, Weiss ST, Cloutier MM. Predictors of disease severity in children with asthma in Hartford, Connecticut. Pediatr Pulmonol. 2005;39:268-75. https://doi.org/10.1002/ppul.20177.

141. Romieu I, Varraso R, Avenel V, Leynaert B. Kauff mann F, Clavel-Chapelon F. Fruit and vegetable intakes and asthma in the E3N study. Thorax. 2006;61: 209-15. https://doi.org/10.1136/thx.2004.039123.

142. Gao J, Gao X, Li W, Zhu Y, Thompson PJ. Observational studies on the effect of dietary antioxidants on asthma: a meta-analysis. Respirology. 2008;13: 528-36. https://doi.org/10.1111/j.1440-1843.2008.01286.x.

143. Wood LG, Garg ML, Smart JM, Scott HA, Barker D, Gibson PG. Manipulating antioxidant intake in asthma: a randomised controlled trial. Am J Clin Nutr. 2012;96:534-43. https://doi.org/10.3945/ajen.111.032623.

144. Wood LG, Garg ML, Powell H, Gibson PG. Lycopene-rich treatments modify noneosinophilic airway inflammation in asthma: proof of concept. Free Radic Res. 2008;42:94-102. https://doi.org/10.1080/10715760701767307.

145. World Cancer Research Fund/American Institute for Cancer Research. Food, nutrition, physical activity, and the prevention of cancer: a global perspective. Washington, DC: AICR; 2007.

146. Ratnasinghe D, Forman MR, Tangrea JA, Qiao Y, Yao SX, Gunter EW, et al. Serum carotenoids are associated with increased lung cancer risk among alcohol drinkers, but not among non-drinkers in a cohort of tin miners. Alcohol Alcohol. 2000;35:355-60.

147. Omenn GS, Goodman GE, Thornquist MD, Balmes J, Cullen MR, Glass A, et al. Risk factors for lung cancer and for intervention effects in CARET, the Beta-Carotene and Retinol Efficacy Trial. J. Natl. Cancer Inst. 1996;88: 1550-9. https://doi.org/10.1093/jnci/88.21.1550.

148. Virtamo J, Pietinen P, Huttunen JK, Korhonen P, Malila N, Virtanen MJ, et al. Incidence of cancer and mortality following alpha-tocopherol and betacarotene supplementation: a postintervention follow-up. JAMA. 2003;290: 476-85. https://doi.org/10.1001/jama.290.4.476.

149. Albanes D, Heinonen OP, Taylor PR, Virtamo J, Edwards BK, Rautalahti $\mathrm{M}$, et al. Alpha-tocopherol and beta-carotene supplements and lung cancer incidence in the alpha-tocopherol, beta-carotene cancer prevention study: effects of base-line characteristics and study compliance. J. Natl. Cancer Inst. 1996;88:1560-70.

150. Abar L, Vieira AR, Aune D, Stevens C, Vingeliene S. Navarro et al. Blood concentrations of carotenoids and retinol and lung cancer risk: an update of the WCRF-AICR systematic review of published prospective studies. Cancer Medicine. 2016;5(8):2069-83. https://doi.org/10.1002/ cam4.676

151. Tricon S, Willers S, Smit HA, Burney PG, Devereux G, Frew AJ, et al. Nutrition and allergic disease. Clin Exp Allergy Rev. 2006;6(5):117-88.

152. Ram FS, Rowe BH, Kaur B. Vitamin C supplementation for asthma. Cochrane Database Syst Rev. 2004;3:CD000993.

153. Mancebo SE, Wang SQ. Recognizing the impact of ambient air pollution on skin health. J Eur Acad Dermatol Venereol. 2015;29:232632. https://doi.org/10.1111/jdv.13250.

154. Sienra-Monge JJ, Ramirez-Aguilar M, Moreno-Macias H, Reyes-Ruiz NI, Del RíoNavarro BE, Ruiz-Navarro MX, et al. Antioxidant supplementation and nasal inflammatory responses among young asthmatics exposed to high levels of ozone. Clin Exp Immunol. 2004;138:317-22. https:/doi.org/10.1111/.1365-2249. 2004.02606.x. 
155. Allen S, Britton JR, Leonardi-Bee JA. Association between antioxidant vitamins and asthma outcome measures: systematic review and metaanalysis. Thorax. 2009;64:610-9. https://doi.org/10.1136/thx.2008.101469.

156. Nurmatov U, Devereux G, Sheikh A. Nutrients and foods for the primary prevention of asthma and allergy: systematic review and meta-analysis. J Allergy Clin Immunol. 2011;127:724-33. e1-30. https:// doi.org/10.1016/j.jaci.2010.11.001.

157. Pearson PJ, Lewis SA, Britton J, Fogarty A, Vitamin E. supplements in asthma: a parallel group randomised placebo controlled trial. Thorax. 2004;59:652-6. https:// doi.org/10.1136/thx.2004.022616.

158. Dunstan JA, Breckler L, Hale J, Lehmann H, Franklin P, Lyons G, et al. Supplementation with vitamins C, E, beta-carotene and selenium has no effect on anti-oxidant status and immune responses in allergic adults: a randomized controlled trial. Clin Exp Allergy. 2007;37:180-7. https://doi.org/10.1111/j.1365-2222.2007.02657.x.

159. Romieu I, Sienra-Monge JJ, Ramirez-Aguilar M, Téllez-Rojo MM, Moreno-Macías $\mathrm{H}$, Reyes-Ruiz NI, et al. Antioxidant supplementation and lung functions among children with asthma exposed to high levels of air pollutants. Am J Respir Crit Care Med. 2002;166:703-9. https://doi.org/10.1164/rccm.2112074.

160. Trenga CA, Koenig JQ, Williams PV. Dietary antioxidants and ozone-induced bronchial hyperresponsiveness in adults with asthma. Arch Environ Health. 2001;56:242-9. https://doi.org/10.1080/00039890109604448.

161. Romieu I, Meneses F, Ramirez M, Ruiz S, Perez Padilla R, Sienra JJ, et al. Antioxidant supplementation and respiratory functions among workers exposed to high levels of ozone. Am J Respir Crit Care Med. 1998;158:226-32. https://doi.org/10.1164/ajrccm.158.1.9712053.

162. Grievink L, Zijlstra AG, Ke X, Brunekreef B. Double-blind intervention trial on modulation of ozone effects on pulmonary function by antioxidant supplements. Am J Epidemiol. 1999;149:306-14.

163. Gref A, Rautiainen S, Gruzieva O, Håkansson N, Kull I, Pershagen G, et al. Dietary total antioxidant capacity in early school age and subsequent allergic disease. Clin Exp Allergy. 2017;47:751-9. https:/doi.org/10.1111/cea.12911.

164. Kurti SP, Murphy JD, Ferguson CS, Brown KR, Smith JR, Harms CA. Improved lung function following dietary antioxidant supplementation in exercise-induced asthmatics. Respir Physiol Neurobiol. 2016;220:95-101. https://doi.org/10.1016/j. resp.2015.09.012.

165. Canova C, Dunster C, Kelly FJ, Minelli C, Shah PL, Caneja C, et al. PM10induced hospital admissions for asthma and chronic obstructive pulmonary disease: the modifying effect of individual characteristics. Epidemiology. 2012;23:607-15. https://doi.org/10.1097/EDE.0b013e3182572563.

166. Wu Q-J, Xiang Y-B, Yang G, Li H-L, Lan Q, Gao Y-T, et al. Vitamin E intake and the lung cancer risk among female nonsmokers: A report from the Shanghai Women's Health Study. Int J Cancer. 2015;136:610-7. https://doi.org/10.1002/ijc. 29016.

167. Virtamo J, Pietinen P, Huttunen JK, Korhonen P, Malila N, Virtanen MJ, et al. Incidence of cancer and mortality following alpha-tocopherol and betacarotene supplementation: a post intervention follow-up. JAMA. 2003;290: 476-85. https://doi.org/10.1001/jama.290.4.476.

168. Lee IM, Cook NR, Gaziano JM, Gordon D, Ridker PM, Manson JE, et al. Vitamin E in the primary prevention of cardiovascular disease and cancer - The Women's Health Study: a randomized controlled trial. JAMA. 2005;294:56-65. https://doi. org/10.1001/jama.294.1.56.

169. The Alpha-Tocopherol, Beta Carotene Cancer Prevention Study Group. The effect of vitamin $\mathrm{E}$ and beta carotene on the incidence of lung cancer and other cancers in male smokers. N Engl J Med. 1994;330:1029-35. https://doi.org/10. 1056/nejm199404143301501.

170. Fortmann SP, Burda BU, Senger CA, Lin JS, Whitlock EP. Vitamin and mineral supplements in the primary prevention of cardiovascular disease and cancer: an updated systematic evidence review for the US Preventive Services Task Force. Ann Intern Med. 2013;159:824-34

171. Zhu YJ, Bo YC, Liu XX, Qiu CG. Association of dietary vitamin E intake with risk of lung cancer: a dose-response meta-analysis. Asia Pac J Clin Nutr. 2017;26(2):271-7. https://doi.org/10.6133/apjcn.032016.04.

172. Narita S, Saito E, Sawada N, Shimazu T, Yamaji T, Iwasaki M, et al. Dietary consumption of antioxidant vitamins and subsequent lung cancer risk: The Japan Public Health Center-based prospective study. Int J Cancer. 2018; https://doi.org/10.1002/ijc.31268.

173. Boonpiyathad T, Chantveerawong T, Pradubpongsa P, Sangasapaviliya A. Serum Vitamin D Levels and Vitamin D Supplement in Adult Patients with Asthma Exacerbation. J Allergy (Cairo). 2016;2016:4070635. https://doi.org/ 10.1155/2016/4070635.
174. Brehm JM, Acosta-Perez E, Klei L, Roeder K, Barmada M, Boutaoui N, et al. Vitamin D insufficiency and severe asthma exacerbations in Puerto Rican children. Am J Respir Crit Care Med. 2012;186:140-6. https://doi.org/10. 1164/rccm.201203-04310C.

175. Paul G, Brehm JM, Alcorn JF, Holguin F, Aujla SJ, Celedon JC. Vitamin D and asthma. Am J Respir Crit Care Med. 2012;185:124-32. https://doi.org/10. 1164/rccm.201108-1502Cl.

176. Brehm JM, Celedón JC, Soto-Quiros ME, Avila L, Hunninghake GM, Forno E, et al. Serum vitamin D levels and markers of severity of childhood asthma in Costa Rica. Am J Respir Crit Care Med. 2009;179:765-71. https://doi.org/ 10.1164/rccm.200808-13610C.

177. Brehm JM, Schuemann B, Fuhlbrigge AL, Hollis BW, Strunk RC, Zeiger RS, et al. Serum vitamin D levels and severe asthma exacerbations in the Childhood Asthma Management Program study. J Allergy Clin Immunol. 2010;126:52-8. e5. https://doi.org/10.1016/j.jaci.2010.03.043.

178. Gupta A, Sjoukes A, Richards D, Banya W, Hawrylowicz C, Bush A, et al. Relationship between serum vitamin $D$, disease severity, and airway remodeling in children with asthma. Am J Respir Crit Care Med. 2011;184: 1342-9. https://doi.org/10.1164/rccm.201107-12390C.

179. Martineau AR, Cates CJ, Urashima M, Jensen M, Griffiths AP, Nurmatov U, et al. Vitamin D for the management of asthma. Cochrane Database Syst Rev. 2016;9:CD011511. https://doi.org/10.1002/14651858.CD011511.pub2.

180. Feng Q, Zhang H, Dong Z, Zhou Y, Ma J. Circulating 25-hydroxyvitamin D and lung cancer risk and survival: A dose-response meta-analysis of prospective cohort studies. Medicine (Baltimore). 2017;96(45):e8613. https:// doi.org/10.1097/MD.0000000000008613.

181. Liu J, Dong Y, Lu C, Wang Y, Peng L, Jiang M, et al. Meta-analysis of the correlation between vitamin $\mathrm{D}$ and lung cancer risk and outcomes. Oncotarget. 2017;8(46):81040-51. https://doi.org/10.18632/oncotarget.18766.

182. Aggarwal BB, Sundaram C, Malani N, Ichikawa H. Curcumin the Indian solid gold. Adv Exp Med Biol. 2007;595:1-75. https://doi.org/10.1007/978-0-38746401-5_1.

183. Yang $X$, LV JN, Li H, Jiao B, Zhang QH, Zhang Y, et al. Curcumin reduces lung inflammation via Wnt/ $\beta$-catenin signaling in mouse model of asthma. J Asthma. 2017:54:335-40. https://doi.org/10.1080/02770903.2016.1218018.

184. Chauhan PS, Dash D, Singh R. Intranasal Curcumin Inhibits Pulmonary Fibrosis by Modulating Matrix Metalloproteinase-9 (MMP-9) in OvalbuminInduced Chronic Asthma. Inflammation. 2017:40:248-58. https://doi.org/10. 1007/s10753-016-0475-3.

185. Khan S, Vala JA, Nabi SU, Gupta G, Kumar D. Telang et al. Protective effect of curcumin against arsenic-induced apoptosis in murine splenocytes in vitro. J Immunotoxicol. 2012;9:148-59. https://doi.org/10.3109/1547691X. 2011.637530.

186. Biswas J, Sinha D, Mukherjee S, Roy S, Siddiqi M, Roy M. Curcumin protects DNA damage in a chronically arsenic-exposed population of West Bengal. Hum Exp Toxicol. 2010;29:513-24. https://doi.org/10.1177/0960327109359020.

187. Waly MI, Ali BH, Nemmar A. Acute effects of diesel exhaust particles and cisplatin on oxidative stress in cultured human kidney (HEK 293) cells, and the influence of curcumin thereon. Toxicol In Vitro. 2013;27:2299-304. https://doi.org/10.1016/j.tiv.2013.09.023.

188. Çelik A, Eke D, Ekinci SY, Yıldırım S. The protective role of curcumin on perfluorooctane sulfonate-induced genotoxicity: single cell gel electrophoresis and micronucleus test. Food Chem Toxicol. 2013;53:249-55. https://doi.org/10.1016/j.fct.2012.11.054.

189. Eke D, Çelik A. Curcumin prevents perfluorooctane sulfonate-induced genotoxicity and oxidative DNA damage in rat peripheral blood. Drug Chem Toxicol. 2016;39:97-103. https://doi.org/10.3109/01480545.2015.1041601.

190. Salahshoor M, Mohamadian S, Kakabaraei S, Roshankhah S, Jalili C. Curcumin improves liver damage in male mice exposed to nicotine. J Tradit Complement Med. 2016;6:176-83. https://doi.org/10.1016/j.jtcme.2014.11.034.

191. Rennolds J, Malireddy S, Hassan F, Tridandapani S, Parinandi N, Boyaka PN, et al. Curcumin regulates airway epithelial cell cytokine responses to the pollutant cadmium. Biochem Biophys Res Commun. 2012;417:256-61. https://doi.org/10.1016/j.bbrc.2011.11.096.

192. Alghasham A, Salem TA, Meki AR. Effect of cadmium-polluted water on plasma levels of tumor necrosis factor-a, interleukin- 6 and oxidative status biomarkers in rats: protective effect of curcumin. Food Chem Toxicol. 2013; 59:160-4. https://doi.org/10.1016/j.fct.2013.05.059.

193. Lin X, Chen Y, Effect LZ. its molecular mechanisms of curcumin on pulmonary artery smooth muscle cells in rat model with chronic obstructive pulmonary disease. Zhejiang Da Xue Xue Bao Yi Xue Ban. 2016;45:469-76. 
194. Gan L, Li C, Wang J, Guo X. Curcumin modulates the effect of histone modification on the expression of chemokines by type II alveolar epithelial cells in a rat COPD model. Int J Chron Obstruct Pulmon Dis. 2016;11:2765-73. https://doi.org/10.2147/COPD.S113978.

195. Zhang M, Xie Y, Yan R, Shan H, Tang J, Cai Y, et al. Curcumin ameliorates alveolar epithelial injury in a rat model of chronic obstructive pulmonary disease. Life Sci. 2016;164:1-8. https://doi.org/10.1016/j.lfs.2016.09.001.

196. Funamoto M, Sunagawa Y, Katanasaka Y, Miyazaki Y, Imaizumi A, Kakeya $\mathrm{H}$, et al. Highly absorptive curcumin reduces serum atherosclerotic low-density lipoprotein levels in patients with mild COPD. Int J Chron Obstruct Pulmon Dis. 2016;11:2029-34. https://doi. org/10.2147/COPD.S104490

197. Ng TP, Niti M, Yap KB, Tan WC. Curcumins-Rich Curry Diet and Pulmonary Function in Asian Older Adults. Shi W, ed. PLoS One. 2012; 7:e51753. https://doi.org/10.1371/journal.pone.0051753.

198. Panahi Y, Ghanei M, Hajhashemi A, Sahebkar A. Effects of CurcuminoidsPiperine Combination on Systemic Oxidative Stress, Clinical Symptoms and Quality of Life in Subjects with Chronic Pulmonary Complications Due to Sulfur Mustard: A Randomized Controlled Trial. J Diet Suppl. 2016;13:93-105. https://doi.org/10.3109/19390211.2014.952865.

199. Lelli D, Sahebkar A, Johnston TP, Pedone C. Curcumin use in pulmonary diseases: State of the art and future. Pharm Res. 2017;115:133-48.

200. Carlsten C, MacNutt MJ, Zhang Z, Sava F, Pui MM. Anti-oxidant Nacetylcysteine diminishes diesel exhaust-induced increased airway responsiveness in person with airway hyper-reactivity. Toxicol Sci. 2014; 139:479-87. https://doi.org/10.1093/toxsci/kfu040.

201. Alhamdan AA. The effect of dietary supplementation of $\mathrm{N}$-acetyl-Lcysteine on glutathione concentration and lipid peroxidation in cigarette smoke-exposed rats fed a low-protein diet. Saudi Med J. 2005;26:208-14.

202. Fowdar K, Chen H, He Z, Zhang J, Zhong X, Zhang J, et al. The effect of $\mathrm{N}$-acetylcysteine on exacerbations of chronic obstructive pulmonary disease: A meta-analysis and systematic review. Heart Lung. 2017;46:120-8. https://doi.org/10.1016/j.hrtlng.2016.12.004.

203. Cazzola M, Calzetta L, Facciolo F, Rogliani P, Matera MG. Pharmacological investigation on the anti-oxidant and anti-inflammatory activity of Nacetylcysteine in an ex vivo model of COPD exacerbation. Respir Res. 2017; 18:26. https://doi.org/10.1186/s12931-016-0500-y.

204. Salve VT, Atram JS. N-Acetylcysteine Combined with Home Based Physical Activity: Effect on Health Related Quality of Life in Stable COPD Patients- A Randomised Controlled Trial. J Clin Diagn Res. 2016; 10:OC16-9. https://doi.org/10.7860/JCDR/2016/23668.8980.

205. Hirai DM, Jones JH, Zelt JT, da Silva ML, Bentley RF, Edgett BA, et al. Oral $\mathrm{N}$-acetylcysteine and exercise tolerance in mild chronic obstructive pulmonary disease. J Appl Physiol (1985). 2017;122:1351-61. https://doi. org/10.1152/japplphysiol.00990.2016.

206. Dunstan JA, Mori TA, Barden A, Beilin LJ, Taylor AL, Holt PG, et al. Fish oil supplementation in pregnancy modifies neonatal allergenspecific immune responses and clinical outcomes in infants at high risk of atopy. a randomized, controlled trial. J Allergy Clin Immunol. 2003:112(6):1178-84. https://doi.org/10.1016/j.jaci.2003.09.009.

207. Mihrshahi S, Peat JK, Webb K, Oddy W, Marks GB, Mellis CM, et al. Effect of omega-3 fatty acid concentrations in plasma on symptoms of asthma at 18 months of age. Pediatr Allergy Immunol. 2004;15(6): 517-22. https://doi.org/10.1111/j.1399-3038.2004.00187.x.

208. British Thoracic Society and Scottish Intercollegiate Guidelines Network. British Guideline on the Management of Asthma. In: The British Thoracic Society; 2016. https://www.brit-thoracic.org.uk/documentlibrary/clinical-information/asthma/btssign-asthma-guideline-2016. Accessed 1 Feb 2018

209. Li XY, Hao L, Liu YH, Chen CY, Pai VJ, Kang JX. Protection against fine particle-induced pulmonary and systemic inflammation by omega-3 polyunsaturated fatty acids. Biochim Biophys Acta. 2017;1861:577-84. https://doi.org/10.1016/j.bbagen.2016.12.018.

210. Zhang F, Yu H, Ni X Zhu J, Wang S, Shen S. Effect of $\omega-3$ polyunsaturated fatty acids on the growth of IEC-6 cells injured by heavy metals. Biomed Rep. 2016;4:635-41. https://doi.org/10.3892/br.2016.621.

211. Biltagi MA, Baset AA, Bassiouny M, Kasrawi MA, Attia M. Omega-3 fatty acids, vitamin $\mathrm{C}$ and $\mathrm{Zn}$ supplementation in asthmatic children: a randomized controlled study. Acta Paediatr. 2009;98:737-42. https://doi. org/10.1111/j.1651-2227.2008.01213.x.
212. Lundstrom SL, Yang J, Brannan JD, Haeggstrom JZ, Hammock BD, Nair P, et al. Lipid Mediator serum profiles in asthmatics significantly shift following dietary supplementation with omega-3 fatty acids. Mol Food Res. 2013;57: 1378-89. https://doi.org/10.1002/mnfr.201200827.

213. Guidetti AM, Cagnozzo R. Beneficial effects of n-3 PUFA on chronic airway inflammatory diseases. Prostaglandins. Other Lipid Mediat. 2012; 99:57-67. https://doi.org/10.1016/j.prostaglandins.2012.09.006.

214. Yates CM, Calder PC, Ed RG. Pharmacology and therapeutics of omega-3 polyunsaturated fatty acids in chronic inflammatory disease. Pharmacol Ther. 2014;141:272-82. https://doi.org/10.1016/j.pharmthera.2013.10.010.

215. Thien FCK, De Luca S, Woods RK, Abramson MJ. Dietary marine fatty acids (fish oil) for asthma in adults and children. Cochrane Database Syst Rev. 2002;2 https://doi.org/10.1002/14651858.CD001283.

216. Barros R, Moreira A, Fonseca J, Ddelgado I, Castel-Branco MG, Haahtela T, et al. Dietary intake of alpha linoleic acid and low ratio of n-6: n-3 PUFA are associated with decreased exhaled NO and improved asthma control. Br J Nutr. 2011;106: 441-50. https:/doi.org/10.1017/S0007114511000328.

217. Beermann C, Neumann S, Fußbroich D, Zielen S, Schubert R. Combinations of distinct long-chain polyunsaturated fatty acid species for improved dietary treatment against allergic bronchial asthma. Nutrition. 2016;32:116570. https://doi.org/10.1016/j.nut.2016.04.004.

218. Snow SJ, Cheng WY Henriquez A, Hodge M, Bass V, Nelson GM, et al. Ozone-Induced Vascular Contractility and Pulmonary Injury are Differentially Impacted by Diets Enriched with Coconut Oil, Fish Oil, and Olive Oil. Toxicol Sci. 2018; https://doi.org/10.1093/toxsci/kfy003.

219. Berthon BS, Macdonald-Wicks LK, Gibson PG, Wood LG. Investigation of the association between dietary intake, disease severity and airway inflammation in asthma. Respirology. 2013;18:447-54. https://doi.org/10. 1111/resp.12015.

220. Romieu I, Barraza-Villarreal A, Escamilla-Nunez C, Texcalac-Sangrador JL, Hernandez-Cadena L, Diaz-Sanchez D, De Batlle J, Del Rio-Navarro BE. Dietary intake, lung function and airway inflammation in Mexico City school children exposed to air pollutants. Respir. Res. 2009;10:122. https://doi.org/ 10.1186/1465-9921-10-122.

221. Li Q, Baines KJ, Gibson PG, Wood LG. Changes in expression of genes regulating airway inflammation following a high-fat mixed meal in asthmatics. Nutrients. 2016:8:30. https://doi.org/10.3390/nu8010030.

222. Vardavas Cl, Flouris AD, Tsatsakis A, Kafatos AG, Saris WH. Does adherence to the Mediterranean diet have a protective effect against active and passive smoking? Public Health. 2011;125(3):121-8. https://doi.org/10.1016/j. puhe.2010.11.012. Epub 28 Jan 2011

223. Wood LG, Garg ML, Gibson PG. A high-fat challenge increases airway inflammation and impairs bronchodilator recovery in asthma. J. Allergy Clin. Immunol. 2011;127:1133-40. https://doi.org/10.1016/j.jaci.2011.01.036.

224. van de Bool C, Rutten EPA, van Helvoort A, Franssen FME, Wouters EFM, Schols AMWJ. A randomized clinical trial investigating the efficacy of targeted nutrition as adjunct to exercise training in COPD. J Cachexia Sarcopenia Muscle. 2017:8:748-58. https://doi.org/10.1002/jcsm.12219.

225. Zhang YF, Lu J, Yu FF, Gao HF, Zhou YH. Polyunsaturated fatty acid intake and risk of lung cancer: a meta-analysis of prospective studies. PLoS One. 2014;12; 9(6):e99637. https://doi.org/10.1371/journal.pone. 0099637.

226. Blusztajn JK,Choline a vital amine. Science. 1998;281:794-5.

227. Zeisel SH, da Costa KA. Choline: an essential nutrient for public health. Nutrition Rev. 2009;67:615-23. https://doi.org/10.1111/j.1753-4887.2009. 00246.x.

228. Mehta AK, Arora N, Gaur SN, Singh BP. Choline supplementation reduces oxidative stress in mouse model of allergic airway disease. Eur J Clin Invest. 2009:39:934-41. https://doi.org/10.1111/.1365-2362.2009.02190.x.

229. Mehta AK, Singh BP, Arora N, Gaur SN. Choline attenuates immune inflammation and suppresses oxidative stress in patients with asthma. Immunobiology. 2010;215:527-34. https://doi.org/10.1016/j.imbio.2009.09.004.

230. Detopoulou P, Panagiotakos DB, Antonopoulou S, Pitsavos C, Stefanadis C. Dietary choline and betaine intakes in relation to concentrations of inflammatory markers in healthy adults: the ATTICA study. Am J Clin Nutr. 2008;87:424-30. 